\title{
THE WEDDING AT CANA (JOH. 2:1-11) IN JUVENCUS, SEDULIUS, AND IN THE TITULI HISTORIARUM
}

\begin{abstract}
Summary: This paper aims to provide a comparative analysis of the Latin metrical rewritings of Joh. 2:1-11 written between the 4th and the end of the 5th century. The first part of the study will provide a thorough commentary to Iuvenc. II 127-152 and Sedul. carm. pasch. III 1-11, highlighting the peculiarities of their approach towards the Gospel narrative and interpreting them in light of the different cultural operations realised by the two paraphrasts. In the second part, peculiar attention will be devoted to the tituli by Prudentius, Ps. Claudian, and Rusticus Helpidius, which provide a much abbreviated 'Umdichtung' of John's pericope, but still reveal some interest in major descriptive and exegetic details; in the conclusion, a brief iconographic survey will try to determine the tituli's most probable iconographic "models".
\end{abstract}

Key words: wedding at Cana, Juvencus, Sedulius, tituli historiarum, Prudentius, Ps. Claudian, Rusticus Helpidius

1. Few literary genres have undergone the same profound critical revaluation which invested in the last decades in the Late Antique biblical paraphrase. After having been almost unanimously neglected as a 'genre faux', since forty years this literary form has become the object of an intense critical debate ${ }^{1}$ particularly stimulating is in my

${ }^{1}$ See at least KARTSCHOKE, D.: Bibeldichtung. Studien zur Geschichte der epischen Bibelparaphrase von Juvencus bis Otfrid von Weißenburg. München 1975; HERZOG, R.: Die Bibelepik der lateinischen Spätantike. München 1975; KIRSCH, W.: Strukturwandel im lateinischen Epos des IV-VI Jhs. Philologus 123 (1979) 38-53; MCCLURE, J.: The Biblical Epic and Its Audience in Late Antiquity. Papers of the Liverpool Latin Seminar 3 (1981) 305-321; ROBERTS, M.: Biblical Epic and Rhetorical Paraphrase in Late Antiquity. Liverpool 1985; NODES, D. J.: Doctrine and Exegesis in Biblical Latin Poetry. Leeds 1993; Deproost, P.-A.: L'épopée biblique en langue latine. Essai de définition d'un genre littéraire. Latomus 56 (1997) 14-39; NAZZARO, A. V.: Poesia biblica come espressione teologica: fra Tardoantico e Altomedievo. In STELla, F. (ed.): La scrittura infinita. Bibbia e poesia in età medievale e umanistica. Firenze 2001, 119-153; NAZZARO, A. V.: Riscritture metriche di testi biblici e agiografici in cerca del genere negato. Auctores Nostri 4 (2006) 397-439; DinKOVA-BRUUN, G.: Biblical Versifications from Late Antiquity to the Middle of the Thirteenth Century: History or Allegory? In OTTEN, W. - POLLMANN, K. (eds.): Poetry and Exegesis in Premodern Latin Christianity. Leiden 2007, 315-342. 
perspective the dynamic of interplay between the underlying biblical hypotext, the expressive models provided by the still influential Latin epic tradition, and the theological themes developed by contemporary Scriptural exegesis. Aiming to provide an operative experiment of analysis, in this paper I will investigate the Latin versifications of the Marriage at Cana; a specific attention will be devoted to the (sub-)genre of the tituli historiarum.

2. The first part of this contribution is dedicated to the transpositions of John 2:1-11 in Juvencus' Euangeliorum libri (II 127-152) and Sedulius' Paschale Carmen (III 1-11). A thorough investigation of these metrical rewritings will show an increasing level of independency from the Scriptural model.

As is well known, the Marriage of Cana finds place only in the Gospel of John (2:1-11), where it represents the first 'sign' ( $\sigma \eta \mu \varepsilon \tilde{\imath} \mathrm{v})$ of Christ's divine nature:

${ }^{1}$ Et tertia die nuptiae factae sunt in Cana Galileae et fuit illic mater Iesum.

${ }^{2}$ Fuit autem Iesus uocitus et discipuli eius ad nuptias. ${ }^{3}$ Et factum est per multam turbam uocitorum uinum consummari mater autem Iesum dixit ad eum uinum non habent fili. ${ }^{4}$ Et respondens Iesus dixit quid mihi et tibi mulier nondum uenit hora mea. ${ }^{5}$ Et aduocatis ad se ministris mater Iesum dixit illis quid uobis dixerit Iesus facite. ${ }^{6}$ Fuerunt autem illic hydriae lapideae sex secundum purificationem Iudaeorum capientes singulae metretas binas uel ternas. ${ }^{7}$ Et Iesus uocitis ad se ministris dixit illis implete hydrias aquam, et impleuerunt eas usque ad summum. ${ }^{8}$ Et ait illis haurite et date archetriclino et fecerunt sicut dixit eis Iesus. ${ }^{9}$ Quomodo autem gustauit archetriclinus aquam uinum factum non intellegebat unde esset ministri autem sciebant qui aurierant aquam quae uinum factum est uocauit autem sponsum archetriclinus. ${ }^{10}$ Et ait illi omnis homo uinum bonum primo ponit et cum inebriati fuerint id quod deterius tu autem seruasti melius uinum usque in hanc horam. ${ }^{11}$ Hoc initium signorum fecit Iesus in Cana Galilaeae et manifestauit gloriam suam et crediderunt in eum discipuli eius. ${ }^{2}$

3. What follows is the versification by the Spanish presbyter Caius Vettius Aquilinus Juvencus, who, in the age of Constantine the Great (probably around 329/330 $\mathrm{AD}$ ), composed the Euangeliorum libri quattuor, the first Latin biblical paraphrase, which retells in 3219 hexameters the history of Christ according to the Gospels (II 127-152):

${ }^{2}$ Since this study takes its moves from Juvencus, I reproduce the Vetus Latina text, in particular that of codex 2 (= Trento, Museo Nazionale, Castello del Buon Consiglio s. n.), which seems to share with Juvencus' (hypothetical) Vorlage at least five parallels: the most significant are the vocative fili (Ioh. 2:3) and the unparalleled adoption of the verb respondeo (Ioh. 2:4), but one should also think to aduocatis ... ministris (Ioh. 2:5), illic (Ioh. 2:6), and date (Ioh. 2:8). For the Vetus Latina text cf. BURTON, P. H. Houghton, H. A. G. - MacLachlan, R. F. - PARKer, D. C. (eds.): Vetus Latina. Die Reste der altlateinischen Bibel. Vol. XIX: Evangelium secundum Iohannem. Freiburg 2011-2013, 145-159. For the text of the Vulgata, on which was in all probability based the later work of Sedulius, cf. WEBER, R. - GRYSON, R. (eds.): Biblia Sacra iuxta Vulgatam versionem. Stuttgart $2007^{5}, 1660$. 
Interea thalamis conubia festa parabant In regione Chanan, ubi clari mater Iesu Nato cum pariter conuiuia concelebrabat. Vina sed interea conuiuis deficiebant.

Tum mater Christum per talia dicta precatur:

"Cernis, laetitiae iam defecisse liquorem?

Adsint, nate, bonis ex te data munera mensis”.

Olli respondit terrarum gloria Christus:

"Festinas, genetrix: nondum me talia cogit

Ad uictus hominum tempus concedere dona”.

Mensarum tunc inde uocat laetata ministros

Mater et imperiis nati parere iubebat.

Sex illic fuerant saxis praepulchra cauatis

Vascula, quae ternis aperirent ilia metretis

Haec iubet e fontis gremio complere ministros.

Praeceptis parent iuuenes undasque coronant

Completis labiis lapidum; tum spuma per oras

Commixtas undis auras ad summa uolutat.

Hinc iubet, ut summo tradant gustanda ministro.

Ille ubi percepit uenerandi dona saporis

Nescius, in uini gratum transisse liquorem

Egestas nuper puris de fontibus undas,

Increpat ignarum sponsum, quod pulchra reseruans

Deteriora prius per mensas uina dedisset.

His signis digne credentum discipulorum

Perpetuam stabili firmauit robore mentem. ${ }^{3}$

Juvencus wanted to entirely rewrite the history of Jesus within the tradition of Latin (especially Vergilian) epic, ${ }^{4}$ at the same time remaining as faithful as possible to the Scripture; in our case, he dedicates twenty-six lines to the eleven verses of John's pericope, taking himself enough space to recall almost every particular of the episode

\footnotetext{
${ }^{3}$ The text is taken from HuEMER, I. (ed.): Gai Vetti Aquilini Iuvenci Evangeliorum libri quattuor. Pragae - Vindobonae - Lipsiae 1891 [CSEL 24], 47-48, with the correction of the erroneous metretris (140; cf. HANSSON, N.: Textkritisches zu Juvencus: mit vollständigem Index verborum. Lund 1950, 13, n. 9; 164, n. 43), also present in WACHT, M.: Concordantia in Iuvenci Evangeliorum libros. Hildesheim Zürich - New York 1990, 174.

${ }^{4}$ On Juvencus' epic tendencies cf. KARTSCHOKE (n. 1) 32-34 and among others ROBERTS, M.: Vergil and the Gospels: The Evangeliorum Libri IV of Juvencus. In REES, R. (ed.): Romane memento: Vergil in the Fourth Century. London 2004, 47-61; HuMMEL, P.: Épisme(s) et épopées dans la littérature chrétienne des premiers siècles. In BOUTET D. - ESMEIN-SARRAZIN, C. (eds.): Palimpsestes épiques. Récritures et interférences génériques. Paris 2006, 161-176; BAZIL, M.: Les débuts de l'épopée biblique au IV siècle : les «Quatre livres des Évangiles » de Juvencus et le « Centon virgilien » de Proba. In DOLEZAlovÁ, L. - Visi, T. (eds.): Retelling the Bible: Literary, Historical, and Social Contexts. Bern - Frankfurt am Mein 2011, 303-312; SANTORELLI, P.: Il Vangelo secondo Giovenco. Auctores nostri 4 (2007) 479-499.
} 
and revealing an evident pursuit of completeness. In particular, he scrupulously adheres to the structure of the Gospel account, as shown by the following scheme:

\begin{tabular}{|l|c|c|}
\hline & Ioh. 2:1-11 & Iuvenc. II 127-152 \\
\hline $\begin{array}{l}\text { spatiotemporal coordinates and } \\
\text { participants in the wedding feast }\end{array}$ & $2: 1-2$ & II 127-129 \\
\hline $\begin{array}{l}\text { the crisis preceding the wonder: } \\
\text { the absence of wine }\end{array}$ & $2: 3 \mathrm{a}$ & II 130 \\
\hline dialogue between Mary and Jesus & $2: 3 \mathrm{~b}-4$ & II $131-136$ \\
\hline the order of the Virgin to the servants & $2: 5$ & II $137-138$ \\
\hline the six vases & $2: 6$ & II $139-140$ \\
\hline the transformation & $2: 7-8$ & II $141-145$ \\
\hline the Weinregel & $2: 9-10$ & II $146-150$ \\
\hline Jesus' first sign & $2: 11$ & II $151-152$ \\
\hline
\end{tabular}

In this passage, Juvencus seems therefore to confirm Jerome's famous statement on his paraphrase, which followed the Scripture 'almost word by word' (vir. ill. 84: paene ad uerbum). ${ }^{5}$ In any case, some differences from the hypotext are also worth of mention: relevant is the absence of the Gospel's precise, albeit unrealistic, chronological determination 'after three days', reassumed by a more vague and epic interea (as quite common in the Euangeliorum libri $^{6}$ ), as well as of any explicit mention of Christ's disciples, whose presence could be in any case inferred from the conclusion of the passage (II 151). To the canonical suppression of cultural Hebraisms, ${ }^{7}$ in this case not due to polemical reasons ${ }^{8}$ but rather to the adherence to interests and expectations of a cultivated Roman audience, has to be ascribed the silence on the purificatory function of the ritual stone jars (Ioh. 2:6).

${ }^{5}$ BiAnco, M. G.: A proposito di aquae rubescunt hydriae. Augustinanum 33 (1993) 52-53: "In Giovenco compare una minuziosa trascrizione in versi del racconto giovanneo che non dà risalto a nessun elemento e a nessun particolare descrittivo."

${ }^{6}$ Rodríguez Hevia, V.: Las fórmulas de transición en Juvenco. Studia Philologica Salmanticensia 5 (1980) 255-271; on interea in Juvencus, see THRAEDE, K.: Zum Beginn der Täuferperikope beim Bibeldichter Juvencus. In HALtenHOFF A. - Mutschler, F.-H. (eds.): Hortus litterarum antiquarum. Festschrift für H. A. Gärtner zum 70. Geburtstag. Heidelberg 2000, 538-539.

7 SPRINGER, C. P. E.: The Gospel as Epic in Late Antiquity: the Paschale Carmen of Sedulius. Leiden 1988, 123: "In general, it is Juvencus' practice to Romanize or simply ignore much of the Jewish background of the Gospel narratives"; for a recent survey on the much debated theme of Juvencus' deJudaisation (or Romanisation) of the Gospel material, cf. SANTORELLI, P.: Introduzione. In CANALI, L. (ed.): Aquilino Giovenco, Il poema dei Vangeli. Milano 2011, 32-34.

${ }^{8}$ PoinsotTE, J.-M.: Juvencus et Israël. La représentation des Juifs dans le premier poème latin chrétien. Paris 1979, 104. 
Beside the reprise of a certain number of terms from the Gospel $^{9}$ (the most significant are ministris and metretis ${ }^{10}$ ), quite evident is, in all the episode, the intention of ennobling John's diction with a large variety of stylistic means, such as poetic synonyms (127: the Grecism thalami for the unmetrical nuptiae; 132: liquor for uinum; 133: natus for filius; 142: iunenes for ministri; 145: summus ... minister for architriclinus; 139-140: saxis ... cauatis / Vascula for the cretic hydriae), pluralia pro singularibus (130; 150: uina; 142; 144; 148: undae), figurae etymologicae (129-130: conuiuia ... / ... conuiuis), alliterations (129: conuiuia concelebrabant; 133: munera mensis; 137: mensarum ... ministros; 142: Praeceptis parent; 143: labiis lapidum), ${ }^{11}$ paronomasias (139: Sex ... saxis; 151: signis digne), and possible reprises from classical poetry. ${ }^{12}$

There are also some minor adiectiones - mainly adjectival ${ }^{13}$ - to the Gospel account; if some are surely exornative (139-140: praepulchra ... / Vascula, with a significant absolute hapax; ${ }^{14}$ with no relation to the hypotext is also the celebration of the purity of water, 148: egestas ... puris de fontibus undas ${ }^{15}$ ), other cases may be

${ }^{9}$ See above n. 2 and the material collected by HeINSDORFF, C.: Christus, Nikodemus und die Samaritanerin bei Juvencus. Berlin 2003, 466-468; significant would be also the reading of Ioh. 2:3 in the codices 13 (= München, Bayerische Staatsbibliothek Clm 6224: cum defecisset uinum) and 6 (= Paris, Bibliothèque Nationale lat. 254: deficiente uino, like in the Vulgate tradition), where the verb is the same of Iuvenc. II 130 and 132. The version of the Vetus Latina known by the paraphrast still remains an open question: in the impossibility to further discuss the question here, I can only refer to MAROLD, K.: Über das Evangelienbuch des Juvencus in seinem Verhältnis zum Bibeltext. Zeitschrift für wissenschaftliche Theologie 33 (1890) 329-341; NestleR, H.: Studien über die Messiade des Juvencus. Passau 1910 (Juvencus used the European Vetus Latina); OrBÁN, A. P.: Juvencus als Bibelexeget und als Zeuge der "afrikanischen" Vetus Latina Tradition. VChr 49 (1995) 334-352 (the poet is a testimony of the African preVulgate text), and now HEINSDORFF 339-353 (Juvencus used an European version of the Vetus Latina, which in any case also reveals the influence of an African text).

${ }^{10}$ Like the old editors F. Arévalo (Romae 1792) and C. Marold (Lipsiae 1886), in his new, unedited edition E. Otero Pereira adopts the reading ilia metris (OTERo PEREIRA, E. [ed.]: C. Vetti Aquilini Iuvenci Evangeliorum Libri quattuor. Edición Crítica. Diss. Salamanca 2010, 142), to avoid the unclassical disyllabic measure of the word ilia (466); on the hardly understandable equivalence metrum = metreta cf. already HUEMER, J.: Kritische Beiträge zur historia evengelica des Juvencus I. WS 2 (1880) 106-107. It has to be also observed that the syneresis already appeared in Ov. am. III 8. 61 (ïliă Sabinas), and that Arator in his Historia apostolica (544 AD) offers a relevant parallel not only to this term, but also to the entire iunctura (II 892: Sic etenim ternas capiunt sex uasa metretas).

${ }^{11}$ On this aspect of Juvencus' paraphrastic technique see DONNINI, M.: L'allitterazione e l'omeoteleuto in Giovenco. AFLPer(class)12 (1974-75) 129-159.

${ }^{12}$ Cf. Stat. silv. III 3. 109-110: festa / Conubia; Theb. III 271-272: conubia ... / Festa; Ov. am. III 13. 3: Casta ... festa parabant; met. VIII 111 (=XI 135): data munera; Verg. Aen. I 563: me talia cogunt $(\mathbf{n}=$ Napoli, Biblioteca Nazionale, Vind. lat. 6, 10th century: cogit); Aen. I 724: uina coronant; georg. IV 499-500: ceu fumus in auras / Commixtus tenuis; Ov. met. III 27: fontibus undas.

${ }^{13}$ On the importance of adjectives in Juvencus' paraphrase see DONNINI, M.: Un aspetto della espressività di Giovenco. L'aggettivazione. Vichiana 2 (1973) 54-67.

${ }_{14}$ Also in Iuvenc. I 427: hominum praepulchra indagine; cf. ThLL X. 2. 787. 48-50.

${ }^{15} \mathrm{It}$ is interesting that also in the Paraphrase by Nonnus of Panopolis the water is 'just spilled'

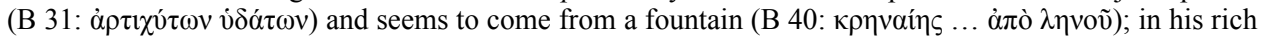
commentary, E. Livrea (Nonno di Panopoli, Parafrasi del Vangelo di S. Giovanni, Canto B. Bologna 2000, 157-158, 200, 214-215) considers these affirmations the trace of 'precise Realien' like the spring of Kafr Kenna, as attested by the Itinerarium Antonini Placentini (CSEL 39, 196, 4: et in ipso fonte ... leuauimus). 
more complex (128: clari ... Iesu ${ }^{16}$ 146: uenerandi ... sapori, ${ }^{17}$; 149: ignarum sponsum $^{18}$ ). In particular, some details may be the textual trace of the poet's edifying intention: ${ }^{19}$ this is quite clear at the end of the episode, where the disciples are called digne credentum discipulorum (151; cf. Ioh. 2:11: et crediderunt in eum discipuli eius), with a pentasyllabic word in clausula, ${ }^{20}$ and the passage is concluded by an insisted amplification of the perpetuity and stability of faith (152: perpetuam stabili firmauit robore mentem; the chiastic scheme is close to the golden line ${ }^{21}$ ). Moreover, at least in one case, Juvencus' addiction could be defined in my opinion 'implicatively exegetical', that is to say, determined by an underlying interpretive approach to the Gospel narrative and by the desire of extending the spiritual resonances of the Cana account. $^{22}$ I am thinking of the definition of wine as laetitiae liquor (132) and gratus

${ }^{16}$ For W. RÖTTGER (Studien zur Lichtmotiv bei Iuvencus. Münster 1996, 28, n. 100), the epithet anticipates the revelation of the 'Hoheit Jesu' before the realisation of the miracle (cf. e. g. Max. Taur. serm. 101. 2: Quomodo autem apparuerit requiramus! Non quod in mundo ante non fuerit, cum mundus per ipsum factus sit, sed quod tunc primum signis atque miraculis credentium cordibus deus Christus inluxerit, et in tenebrosas conscentias hominum fides splendoris aduenerit); but R. F. GLEI (Jesus als Gottmensch in lateinischer Bibelepik. In G. BINDER - B. EFFE - R. F. GLEI [Hrsg.]: Gottmenschen. Konzepte existentieller Grenzüberschreitung im Altertum. Trier 2003,138, n. 15) rightly underlines the poor semantic value of the attribute in similar contexts; for SANTORELLI, P.: I libri dei Vangeli. II. Introduzione e commento. Pisa 2005, 117, "l'aggettivo ha il significato di serenus".

${ }^{17}$ For R. P. H. GREEN (Latin Epics of the New Testament: Juvencus, Sedulius, Arator. Oxford $2006,125)$ the 'gifts of the veritable taste' may constitute the hint of an Eucharistic interpretation, since the epithet always possesses in Juvencus a solemn value.

${ }^{18}$ For P. SANTORELli (Commento. In CANALI [n. 7] 300), the 'absolute extraneousness' of all other participants stresses the complicity between Mary and Christ; cf. also SANTORELLI: I libri (n. 16) $117-118$.

${ }^{19}$ In the homiletic genre, the disciples of Cana provide an example of faith for all Christians, cf. Max. Taur. serm. 103. 1: Quod factum non ideo tantum scriptum est, ut illorum sub quibus factum est fidei gloria monstraretur, sed et propter nos, qui eodem deuotionis exemplo ad credulitatis gloriam prouocamur. Christus enim quod operatus est non illis tantum operatus est, quos habebat tunc praesentes, sed et nobis postea secuturis, ut licet maiores nostri tempore nos praecederent, tamen signorum gratia non praeirent; 3: Magnificanda igitur apostolorum fides quae ideo euangelico sermone descripta est, ut et illis esset ad laudem et nobis proficeret ad exemplum.

${ }^{20}$ Juvencus has forty-six pentasyllabic clausulae (cf. in our episode also II 129: concelebrabat; II 130: deficiebat), showing for this aspect to be more 'Lucretian' than Vergilian: in the Mantuan poet, the pentasyllabic clausulae are just nineteen, and only one of them - Aen. XI 614 - has no Greek origin; cf. FLAMMINI, G.: La struttura dell'esametro degli Evangeliorum libri di Giovenco. AFLM 32 (1999) 286-287.

${ }^{21}$ Quite interestingly, Juvencus never says that Cana was Christ's first miracle, and prefers to stress the concepts of continuity and stability of faith; it is also true that "according to the Euangeliorum libri quattuor, the stilling of the storm (2. 25-42) and other miracles of Christ precede the wedding at Cana" (SPRINGER [n. 7] 123). As explained by A. SMITMANS (Das Weinwunder von Kana. Tübingen 1966, 145147), the fact that often - especially in the West - the miracle of Cana was not explicitly defined 'Christ's first sign' might be considered the result of the large diffusion of the apocryphal Infancy Gospels (cf.

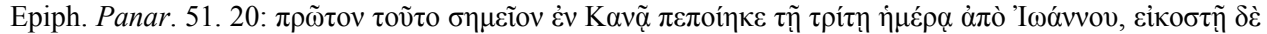

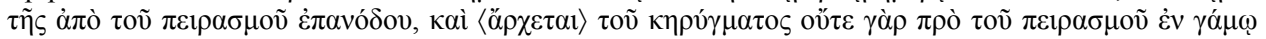

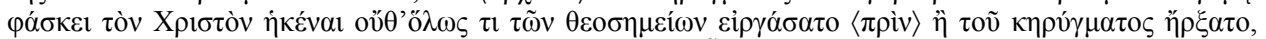

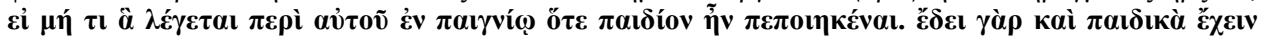

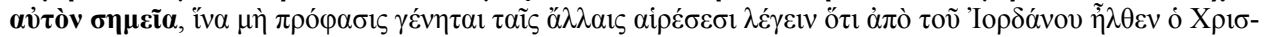

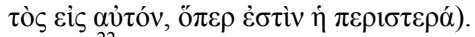

${ }^{22}$ I rely on the perspective of R. P. H. GREEN (The Evangeliorum Libri of Juvencus: Exegesis by Stealth? In Otten, W. - Pollmann, K. [eds.]: Poetry and Exegesis in Premodern Latin Christianity. 
liquor (147): ${ }^{23}$ this detail is an allusion to Ps. 104:15 (et uinum laetificat cor homi$n i s)^{24}$ and surely remarks, at a first level, the pleasant effects of wine and the joyful atmosphere of the marriage feast, ${ }^{25}$ but probably also alluded for the poet to the spiritual joy brought by Christ-uera uitis, ${ }^{26}$ as we will more explicitly see in Sedulius.

Extremely relevant is in Juvencus the role played by the Virgin, repeatedly de-

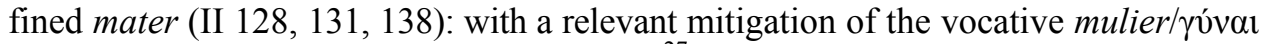
of Ioh. 2:4, Jesus himself calls her genetrix, ${ }^{27}$ and it could be said that her maternal presence also determines the definition of the role of Christ, since He is for three times called natus (II 129, 133, 138). The centrality of this theme is also strengthened by the fact that the only dialogic exchange preserved by Juvencus is the one between Mary and Jesus; all other direct speeches are transformed in indirect discourses, following a common strategy of Juvencus' paraphrastic technique. ${ }^{28}$ It is evident that the Spanish presbyter did not want to renounce to the dramatic power of the dialogue between Mary and her Son, but at the same time tried to simplify its somehow mysterious content: ${ }^{29}$ Mary's statement (Ioh. 2:3b: uinum non habent, fili), with a notable 'modal variation', ${ }^{30}$ is expanded in two sentences, a question (II 132: Cernis, laetitiae iam defecisse liquorem?) and an explicit invocation (II 133: Adsint, nate, bonis ex te data munera mensis), and Christ's answer (Ioh. 2:4: quid mihi et tibi mulier nondum uenit hora mea) is at the same time less sharp and more transparent in its 'eucha-

Leiden - Boston 2007, 80), who sees in some parts of Juvencus' work 'a response to certain trends fundamentally, exegetical trends' rather than a direct, autonomous confrontation with exegetical themes.

${ }^{23}$ For GREEN (Latin Epics [n. 17] 125), instead, "laetitiae ... liquorem is probably without any such significance; if anything it is aimed against an ascetic aversion to the drinking of wine".

${ }^{24}$ The presence in Juvencus of a "heterogenous quotation", closer to the logic of commentary than to that of paraphrasis, should lead to a partial integration of the however useful contribution by BUREAU, B.: Citer et/ou paraphraser chez quelques poètes bibliques latins: Juvencus, Sedulius, Arator. In DARBOPESCHANSKI, C. (ed.): La citation dans l'Antiquité. Grenoble 2004, 209 ("Cette pratique, qui est très intimement liée à l'évolution même du genre vers une fonction plus explicative que narrative, n'apparaît pas chez Juvencus, entièrement occupé à reformuler le contenu des péricopes évangéliques").

${ }^{25}$ Cf. Ps. Cypr. rebapt. 8: quod aquam in uinum conuertendo conuiuium nuptiale admirabili laetitia amplificaret; Appon. cant. 9. 34: pulchritudinem suam, obfuscatis tristitiae nubibus, nuptiis demonstrauit.

${ }^{26}$ KollmanN, B.: Jesus und die Christen als Wundertäter. Göttingen 1996, 280, n. 31. After Juvencus, this interpretation is attested by Ephrem the Syrian (LELOIR, L. [ed.]: Commentaire de l'évangile concordant, texte syriaque (ms. Chester Beatty 709). Dublin 1963, 77: In initium signorum suorum fecit uinum laetificans conuiuio, ut patefaceret sanguinem suum laetificaturum esse omnes gentes. Omnia gaudia quae sunt, in uino coniunguntur; et omnes saluationes quae factae sunt, in magisterio sanguinis eius coniunguntur), Gaudentius (tract. 8. 6: Quid est ergo, quod ista euangelii lectio, quae hodie recitata est, festiuitati nuptiali interfuisse dominum perhibet inuitatum, nisi quod ibi uinum, id est uirtus defecerat laetitiae spiritalis, et languebant sitientium turbae uocatorum uini laetificantis inopia, quoniam uinum laetificat cor hominis, ut ait propheta), and Cyril of Alexandria (in Ioh. tract. 2. 1-4, PG 73,

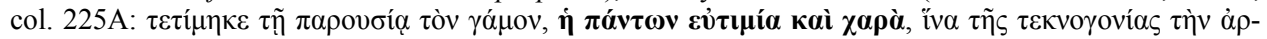

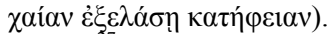

${ }^{27}$ SANTORELLI: I libri (n. 16) 117. In the 5th century, the application of this term to the Virgin was criticized by $\mathrm{Cl}$. Mamertus because of its too materialistic connotation (stat. anim. 3. 6).

${ }^{28}$ SimONETTi AbBolito, G.: Osservazioni su alcuni procedimenti compositivi della tecnica parafrastica di Giovenco. Orpheus 6 (1985) 319-320.

${ }^{29}$ GLEI (n. 16) 140-141. On the exegesis of Ioh. 2:4 in the Fathers cf. SMITMANS (n. 21) 97-125, $244-253$.

${ }^{30}$ ROBERTS (n. 1) 141-142. 
ristische Spiritualisierung' (II 135-136: Festinas, genetrix; nondum me talia cogit / Ad uictus hominum tempus concedere dona), to which in particular clearly alludes the expression uictus hominum. ${ }^{31}$

Between the two lines symmetrically dedicated to the speeches of the Virgin (II 132-133) and of Christ (II 135-136), the solemn 'Redeeinleitung',32 Olli respondit terrarum gloria Christus constitutes the focal point (and, literally, the centre) of the dialogic section, and also represents an interesting Christological expansion, as already underlined by R. F. Glei. ${ }^{33}$ This happens not only in reason of the 'ersetzende Übertragung' of the epithet terrarum gloria with regards to Jesus (Mart. II 91. 1: Rerum certa salus, terrarum gloria, Caesar ${ }^{34}$ ), but also of the adoption, in first position, of the solemn dative pronoun olli. ${ }^{35}$ The reason of this morphological archaism may be just stylistic, since Juvencus uses other three times the iunctura olli ... respondit to introduce a solemn dialogue; it has been also suggested that the poet wanted to imitate Ennius, since the same word association at the beginning of a hexameter found place in a famous fragment of the Annales (33 Vahlen ${ }^{2}$ : Olli respondit rex Albai Longai), a holospondaic line renowned for its solemnity. ${ }^{36}$ For my part, I am inclined to believe that Juvencus may have had in mind a famous Vergilian passage, the dialogue between Jupiter and Juno at the end of the Aeneid, and in particular the introduction of the speech (XII 829: Olli surridens hominum rerumque repertor) ${ }^{37}$ where the king of gods accepts his wife's requests on the future destiny of Latium (XII 833: Do

${ }^{31}$ HerzOG (n. 1) 122-123; GREEN: Latin Epics (n. 17) 125; see also HERZOG, R.: Exegese - Erbauung - Delectatio. In HAUG, W. (ed.): Formen und Funktionen der Allegorie. Symposion Wolfenbüttel 1978. Stuttgart 1979, 59-61, for an interpretation of Juvencus' 'poetisierte Exegese', obtained within the 'paraphrastischer Spielraum' by means of 'paraphrastische Intensität'. E. COLOMBI (Paene ad verbum: gli Evangeliorum libri di Giovenco tra parafrasi e commento. Cassiodorus 3 [1997] 16-17) draws a parallel between Juvencus' poem and the Eucharistic interpretations of the Cana account already present in Irenaeus (adv. haer. III 16. 7), Origen (ser. in Matth. 74. 97), and Cyprian (epist. 63. 12-13).

${ }^{32}$ For such forms of "expanded introductions" to direct speeches with epithets (I 27: Olli confusa respondit sacerdos; II 118: Talibus attoniti sequitur uox Nathanahelis; II 265: Olli respondit mundi regnator lesus; III 161: Tum sator aeternae respondit talia uitae; III 503: His auctor uitae tum talia reddit lesus) cf. CAstro Jiménez M. D. - Cristóbal V. - MAuro Melle, S.: Sobre el estilo de Juvenco. CFC 22 (1989) 136.

${ }^{33}$ GLEI (n. 16) 143. I am less convinced that, in the rest of the episode, the poet wanted to explicitly stress Christ's humanity by particularly emphasising His participation to the marriage feast (143: "Es wird ausdrücklich betont, dass Jesus und Maria mitfeierten [...], also normale Gäste unter den anderen waren; der Dialog zwischen Maria und Jesus zeugt bei Juvencus von einem ungetrübten Mutter-Sohn-Verhältnis, und Jesus legt nicht die erhabene Schroffheit des zu Höherem Berufenen, sondern hintersinnigen Humor an den Tag"): this element, in fact, already appears in the Gospel.

${ }^{34}$ SANTORELLI: I libri (n. 16) 120: "Esplicito è il riferimento a Mart. 2. 91.1 [...] infatti non solo l'epiteto terrarum gloria occupa lo stesso posto nell'esametro, ma in tutti e due i casi è un nome proprio che chiude il verso; inoltre anche il nesso certa salus è ripreso al v. 285"; cf. also Lucan. IV 595: Nec tam iusta fuit terrarum gloria Typhon.

${ }^{35}$ The archaic form of the pronoun was appreciated by the paraphrast: cf. I 27 (Olli ... respondit); I 428; II 14; II 152; II 265 (Olli respondit); II 410; II 412; III 110 (Olli ... respondit); III 659; III 677; III 703; IV 29; IV 525.

${ }^{36}$ Cf. CASTRO JimÉNEZ - CRISTÓBAL - MAURO Melle (n. 32)147-148.

${ }^{37}$ In his apparatus, Huemer (followed by SANTORELLI: I libri [n. 16] 120) cited as possible model Verg. Aen. XII 18 (Olli sedato respondit corde Latinus); for GLEI (n. 16) 143 the presbyter alluded instead to the Vergilian line Olli subridens hominum sator atque deorum (Aen. I 254), also referred to Jupiter. 
quod uis, et me uictusque uolensque remitto). The hypothesis of an intertextual memory seems reinforced by the contextual application of the participle laetata (II 137) to Mary, relieved after the answer of Her Son: this innovation from the hypotext has been variously explained by scholars, ${ }^{38}$ but the detail may well come from Vergil, since the participle is also applied to Juno in the first line after the conclusion of Jupiter's answer (XII 841: Adnuit his Iuno et mentem laetata retorsit).

In conclusion, we should also note that Juvencus transformed the essential report of Ioh. 2:7 in a rich, epic description of the transformation, ${ }^{39}$ revealing his desire to depict the scene as a process in fieri: as we will see, this characteristic will be also shared by the later versifications of the episode, under the probable influence of the Ovidian technique in portraying metamorphic processes, and perhaps also of the similar approach to Cana by Palaeo-Christian iconography. As for what pertains Juvencus' literary models, 11. 142-145 may contain not only a memory of Verg. Aen. I 274 (uina coronant), ${ }^{40}$ but also a still unnoticed intertextual reference ${ }^{41}$ to the beginning of the second book of the Georgics. Here Virgil addresses a famous invocation to Bacchus, depicting the grape harvest that foams in full-to-brimming vats (II 4-8: Huc, pater o Lenaee (tuis hic omnia plena / Muneribus, tibi pampineo grauidus autumno / Floret ager, spumat plenis uindemia labris), / Huc, pater o Lenaee, ueni). The Spanish priest may have borrowed from Vergil the mention of foam (II 142: spuma), a detail which reveals that water has already turned into wine, ${ }^{42}$ and the expansion of the particular (whose preciousness has been also noted by R. P. H. Green ${ }^{43}$ ) of the jars being filled to the brim (II 142: Completis labiis; at 1. 143, ad summa is more directly influenced by the hypotext).

However that may be, Juvencus' meticulous paraphrase has revealed to be a complex literary operation, consisting in the 'intercultural translation' 44 of the Gospel

${ }^{38}$ DE WIT, C.: Ad luvenci Evangeliorum librum secundum commentarius exegeticus. Groningae 1947, 43: "Maria laetatur, quia intellegit Iesum mox facturum, quod ab eo petierit"; the same interpretation in GLEI (n. 16) 141. Mary's reaction was a sign of 'diffuse Emotionalität' for HERZOG: Exegese (n. 31) 60.

${ }^{39}$ GLEI (n. 16) 142: "Juvencus hat es geschickt verstanden, die (vermeintliche) Lücke im Bibeltext - das Fehlen der eigentlichen Metamorphose - mit epischen Mitteln zu schließen, ohne allzusehr in den Text einzugreifen."; SANTORELLI (n. 16) 123: "Nei tre versi il poeta dà vita ad una descrizione del tutto estranea al testo biblico, sulla quasi si sofferma con un compiacimento palpabile: in maniera minuziosa rende la maniera e il preciso momento in cui avviene la formazione della schiuma".

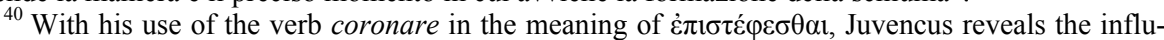

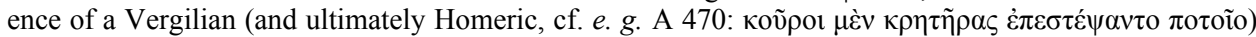
commentary - perhaps that of Aemilius Asper -, as recently shown by GNILKA, CH.: Spuren antiker Vergilerklärung bei Juvencus. In FREUND S. - VIELBERG, M. (eds.): Vergil und das antike Epos. Festschrift Hans Jürgen Tschiedel. Stuttgart 2008, 387-393.

${ }^{41}$ For HeRzoG (Exegese [n. 31] 60, n. 59), Juvencus had in mind Vergil's description of Silvius (Aen. VI 760-762: Ille, uides, pura iuuenis qui nititur hasta, / Proxima sorte tenet lucis loca, primus ad auras / Aetherias Italo commixtus sanguine surget), also recalled in IV 703.

${ }^{42}$ Cf. the alternative suggestion by GNILKA (n. 40) 392: "Auf diesen Einfall brachte ihn vielleicht dieselbe Vergilsstelle, der er den Ausdruck (undasque) coronant entnahm. Denn nachdem Dido dem Jupiter eine Weinspende dargebracht und selbst vom Wein genippt hat, reicht sie dem Bitias spumantem pateram (Aen. I 739)." For a similar case where foam reveals a transformative process, cf. infra Sil. VII 188.

${ }^{43}$ GREEN: Latin Epics (n. 17) 49-50.

${ }^{44}$ On this aspect see STELLA, F.: Imitazione interculturale e poetiche dell'alterità nell'epica biblica latina. Incontri Triestini di Filologia Classica 5 (2005-2006) 9-24, where biblical poetry is considered as 
narrative adopting the metre and the expressive forms of the Latin pagan epic tradition; Juvencus' close adherence to the hypotext, and his aversion for any explicit form of 'versified hermeneutic', does not prevent the poet to operate some minor additions to the Scripture, at least in one case probably motivated by the intention of increasing the spiritual enrichment of the narration.

4. Roughly a century after Juvencus, in the five books of his Paschale Carmen (c. 420-450 AD), Coelius Sedulius shows a very different approach towards the biblical hypotext. Less interested in the respect of biblical chronology ${ }^{45}$ and much more selective than his predecessor (the work is composed by only 1753 hexameters), he does not aim to a continuous and faithful paraphrase, but rather to an elaborate 'Umdichtung' - and often interpretation - of relevant episodes from the Gospels. ${ }^{46}$ In the eleven lines dedicated to Cana (the collocation at the very beginning of the third book is strategic, and it could not be casual that eleven are also the verses of John's pericope), Sedulius shows a very high independency in recasting the Gospel original (pasch. carm. III 1-11):

Prima suae Dominus thalamis dignatus adesse

Virtutis documenta dedit conuiuaque praesens

Pascere, non pasci ueniens, mirabile! fusas

In uinum conuertit aquas: amittere gaudent

Pallorem latices, mutauit laeta saporem

Vnda suum largita merum, mensasque per omnes

Dulcia non nato rubuerunt pocula musto.

Impleuit sex ergo lacus hoc nectare Christus:

Quippe ferax qui uitis erat, uirtute colona

Omnia fructificans, cuius sub tegmine blando

Mitis inocciduas enutrit pampinus uuas. ${ }^{47}$

Since from a first reading, the poet reveals his distance from John (in particular, he does not provide any temporal or local setting for the miracle, ${ }^{48}$ nor does he recall the

an attempt to "creare un codice adatto all'espressione di contenuti semitici o elleno-semitici con strumenti della tradizione letteraria occidentale".

${ }^{45}$ On the third book cf. LEIMBACH, C. L.: Über den christlichen Dichter Caelius Sedulius und dessen Carmen Paschale. Goslar 1879, 17: "Mit allen Evangelienharmonien wird Sedulius sicher in Conflikt treten, falls es ihm auf eine chronologisch geordnete Aneinderreihung der Taten und Leiden Christi ankam."

${ }^{46}$ KARTSCHOKe (n. 1) 41-45; Dermot SMAll, C.: Rhetoric and Exegesis in Sedulius. C\&M 37 (1986) 224: "Sedulius' poem is no mere versification of the Biblical narrative but a carefully constructed composition in which the poet encourages the reader to look beyond the literal sense in order to witness the essential spiritual message of the events of Christ's life."

${ }^{47}$ HUEMER, H. (ed.): Sedulii opera omnia, editio altera supplementis aucta curante V. PANAGL [CSEL 10]. Wien 2007, 65.

48 This is typical of Sedulius' work, where the consequential ties between episodes are often very weak, giving origin to purely juxtapositive sequences; cf. OPELT, I.: Die Szenerie bei Sedulius. VChr 29 (1975) 191-207 and, for what pertains the miracle of Cana, SPRINGER (n. 7) 112: "The poet is never very interested in locating his episodes in time and space. Sedulius most often will begin an episode with a vague dehinc (3. 207), praeterea (4.31), or post (4. 64). In 3. 1-11 the poet ignores the evangelist's fairly 
presence at the Wedding of the Virgin and the Apostles ${ }^{49}$ ) and also from his predecessor Juvencus: common is only the traditional poetism thalamis to substitute nuptiae. John's account is reduced to its central moment, that of the transformation (Ioh. 2:7), conveyed in less than two lines (3b-4a: fusas / In uinum conuertit aquas; 8: Impleuit sex ergo lacus hoc nectare Christus, which also constitutes an introduction to the following exegesis). For the rest, the poet appears closer to the Latin epic tradition, partially transfigured by means of an 'epigrammatic' focus on the decisive instant of metamorphosis: in his rich commentary to Sedulius' third book, M. Mazzega ${ }^{50}$ already proposed a parallel with the so-called 'epyllion of Falernus' from Silius' Punica (VII 162-211), ${ }^{51}$ dedicated to the visit of a disguised Bacchus, sacri / Largitor laticis (VII 163-164), to the region of Mount Massicus. In Silius, the hospitality provided to Bacchus by the aged farmer Falernus constitutes the aetiological myth for the homonymous wine. This description of a 'Weinverwandlung' (where it also appears a styleme like mirabile! - with a rhetorical-affective connotation ${ }^{52}$, which was also a theophany (VII 194: et haud ultra latuit deus), may have inspired Sedulius, also because, as is well known, John does not reveal any detail of transformation, but only its final result (VII 186-191):

\section{Desse tuos latices hac sedulitate senili \\ Captus, Iacche, uetas. Subito, mirabile dictu, \\ Fagina pampineo spumarunt pocula suco, \\ Pauperis hospitii pretium, uilisque rubenti \\ Fluxit mulctra mero, et quercu in cratera cauata \\ Dulcis odoratis umor sudauit ab uuis.}

In the Paschale Carmen, the vivacity of the description is enriched by a large display of synonyms for water (4: aquae; 5: latices; 6: unda) and wine (4: uinum; 6: merum; 7: mustus; 8: nectar); as pointed out by M. G. Bianco, peculiar of Sedulius ${ }^{53}$ is in

precise setting of the event (die tertia and Cana Galilaeae). Here as elsewhere in the Paschale Carmen Sedulius' concern is with inner landscape, the mystical realm rather than the physical."

${ }^{49}$ SPRINGER (n. 7) 113: "As elsewhere in the Paschale Carmen, Sedulius is less concerned with minor characters in the Gospels, even the disciples, than he is with Christ, who moves through a world rendered somewhat remote by his divine superiority."

${ }^{50}$ MazzeGA, M.: Sedulius, Carmen paschale, Buch III. Basel 1996, 63-74.

${ }^{51}$ This passage was studied by VeSSEY, D. W. T. C.: The Myth of Falernus in Silius, Punica 7. CJ 68.3 (1973) 240-246; on Bacchus' 'Weinverwandlung' cf. also VON ALBRECHT, M.: Silius Italicus. Freiheit und Gebundenheit römischer Epik. Amsterdam 1964, 155-157; for a contextual and intertextual interpretation cf. FUCECCHI, M.: La tradizione dell'epillio in Silio Italico. Centopagine 2 (2008) 39-48.

52 This insertion produces the typical 'Relief' that emphasises the 'Wunderparaphrase' (HERzOG: Die Bibelepik [n. 1] 143), by underlining the most extraordinary aspect of the miracle (MAZZEGA [n. 50] 67-68).

${ }^{53} \mathrm{Cf}$. in any case also Ambr. in Luc. 6. 87: Sic in nuptiis ex fontibus uina ministris operantibus colorantur et ipsi qui inpleuerant hydrias aqua uinum quod non detulerant hauriebant; hymn. 7. 17: Aquas colorari uidens; Gaud. Brix. tract. 11. 4: Iam liquorem simplicissimum perlucentis aquae in colorem saporemque uini sua potestate conuerterat; Max. Taur. serm. 101. 3: Aqua enim uilis pallida et frigida in uinum uersa, scilicet pretiosum rubrum uel ignitum; 103. 2: Aqua in uinum uersa sapore rubore calore conditur. The red colour of wine is also relevant in the contemporary Paraphrase of the Gospel of

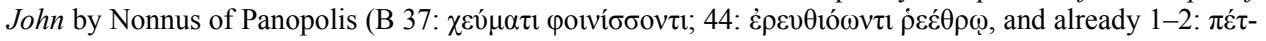
$\rho \alpha \varsigma / \pi о \rho \varphi v \rho \varepsilon ́ \alpha \varsigma)$; cf. LIVREA (n. 15) 153-154, 209. 
particular the depiction of the transformation as a chromatic process, by means of the verb rubeo (the inchoative rubesco is used in the hymn $A$ solis ortus cardine ${ }^{54}$ ). In any case, Sedulius' paraphrastic technique is not entirely reducible to a superimposition of rhetorical colores to biblical material: even in the first eight lines, mainly dedicated to a sophisticated description of the metamorphosis, some details also contribute to the pursuit of a precise 'Erbaulichkeit'. From the very first line, Christ is defined Dominus, stressing His role as Creator, ${ }^{55}$ and with a notable chiastic hyperbaton (and a significant anticipation from Ioh. 2:11), we are immediately informed that the wonder of Cana was Christ's first $\sigma \eta \mu \varepsilon i ̃ o v$, the first demonstration of His divine nature (Prima suae ... / Virtutis documenta ${ }^{56}$ ). This information, notably absent from Juvencus' paraphrase, also appeared in the ancient Psalmus responsorius (93-94: Magnum mirabile signum fecit / In Galilea, qua primum ibit), in Nonnus' Paraphrase (B, 55-

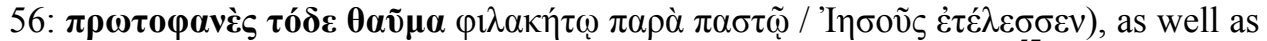
in Paulinus of Nole, Ps. Claudian and Rusticus Helpidius (cf. infra). ${ }^{57}$ In His infinite superiority, the Lord condescends (dignatus adesse substitutes uocatus est) to partake in the marriage feast, ${ }^{58}$ but has nothing in common with the other guests: as Sedulius' inclination to paradoxes puts it, he came 'to nourish, not to be nourished', 59 with an antithetic polyptoton later used also by Bede in his Vita Cuthberti (pascere, non pasci ueniens). ${ }^{60}$ As already pointed out by Remigius of Auxerre, ${ }^{61}$ Sedulius humanises

${ }^{54}$ Sedul. hymn. 2. 49-52 (Nouum genus potentiae: / Aquae rubescunt hydriae / Vinumque iussa fundere / Mutauit unda originem), on which cf. BIANCO (n. 5) 49-56. For the scholar, Sedulius' chromatic auxesis may also allude to the redemptive blood of Christ: "Senza dubbio la prima evocazione del verbo rubesco sembra essere quella di Io 19, 34 e 6, 54-57 e sembra collegare la redenzione operata dal sangue di Cristo e l'inserimento dell'umanità nella redenzione. Tale inserimento comporta un cambiamento nell'essere umano, il passaggio dall'acqua al vino, dal peccato alla salvezza, dall'avere sapore di acqua all'avere gusto piacevole e dolce di vino. Questa è opera del Cristo salvatore e si compie nella vita sacramentale, nell'eucarestia in particolare" (56); to BIANCO's exegetical parallels $(52, \mathrm{n} .8)$ one should add the clear testimony of Maximus of Turin (serm. 101. 3, cf. infra); on the allegorical interpretations of the Fathers, cf. also WuCHERPFENNIG, A. SJ: Die Hochzeit zu Kana. Erzählperspektive und symbolische Bedeutung. Theologie und Philosophie 79 (2004) 326-328.

${ }^{55}$ MAZZEGA (n. 50) 65.

${ }^{56}$ Miracles are called documenta uirtutis et potestatis already by Tertullian (adv. Marc. IV 35. 5); for Cana, cf. Gaud. Brix. tract. 9.37 (Dominus Iesus inuisibili uirtute hanc aquam conuertit in uinum); Max. Taur. serm. 64. 1 (Primum hoc mirabili signo diuinitatis suae declarasse uirtutem); Appon. cant. 9. 34 (Per signorum uirtutes, aquam in uinum mutando, pulchritudinem suam [...] demonstrauit).

${ }^{57}$ Without taking in consideration the Psalmus responsorius and Paulinus of Nole, in his comparative analysis SPRINGER (n. 7), 123 affirms that "only the author of Miracula Christi and Rusticius Helpidius tell us that it was Jesus' first miracle".

${ }^{58} \mathrm{Cf}$. Ambrosiast. quaest. 127. 7: Ipse enim rogatus ad nuptias ire non dedignatus est et non solum praesentia sui inlustrauit eas, uerum etiam contulit quod deerat ad laetitiam.

${ }^{59}$ SPRINGER (n. 7) 124: "Sedulius' expansion [...] does not limit itself to stylistic periphrasis but actually introduces a new idea into the narrative. The fifth-century poet helps the reader to anticipate the outcome of the episode by suggesting in a pregnant expression what the guest (who is also a host) will do before the wedding is over"; cf. also MAZZEGA (n. 50) 66.

${ }^{60}$ Bed. vita Cuth. 7. 1; vita Cuth. metr. 206: these references do not appear in HUEMER's Index scriptorum qui vel citaverunt vel imitati sunt Sedulium (n. 47) 368.

${ }^{61}$ Remigius of Auxerre, Excerpta ex Remigii expositione in Paschale Carmen (HUEMER [n. 47] 338): Fantasia, imaginatio quaedam poetae est, quoniam insensibili rei dat sensum ut desinerent esse quod [non] erant, et inciperent esse quod non erant. 
material reality: for the poet, in fact, the miracle of Cana reveals the intimacy of the relation between natural elements and their Creator, ${ }^{62}$ and the joyful participation of nature in Christ's transformative activity (4-5: amittere gaudent / Pallorem latices; 5-6: laeta / Vnda) ${ }^{63}$ very similarly, already in the hymn Inluminans altissimus ${ }^{64}$ human feelings (in that case, wonder) were attributed to the transformed water of Cana (hymn. 7. 19-20: Elementa mutata stupet / Transire in usus alteros).

Coherently with the polarisation of the scene in an exclusive relation between God and nature, Christ stands as the only protagonist of the miracle, and His manipulative activity on natural laws does not need any intermediates: even if impleuit (8) is probably used with causative meaning, it is relevant that for Sedulius is Christ himself, and not the servants, who fills up the six water vases. A rhetorical stress on the excellence of transformation is also evident: if for C. Springer the wine's elaborate description responds to Sedulius' painterly interest, ${ }^{65}$ it has to be remembered that the superiority of the 'not-born wine' of Cana was also celebrated by Ambrose, showing the Creator's complete power over nature (in Luc. VI 87):

Melior est mutati uini natura quam nati, quia in arbitrio creatoris est et quos usus uelit adsignare naturis et quas naturas inpertire gignendis.

In the last three lines, Sedulius acquires an explicitly interpretive tone (it has been acutely affirmed that he often treats miracles as if they were parables ${ }^{66}$ ) and provides his exegesis of the wonder. If the main content of the image is clear, ${ }^{67}$ the intersection of biblical sources is probably more complex than it may seem, originating a sort of

${ }^{62}$ Cf. Max. Taur. serm. 101. 3: Quis enim non miretur in aliud quam erant elementa esse translata? Nemo enim potest mutare naturam nisi qui dominus est naturae; Petr. Chrys. serm. 157. 4: Denique ubi aquae mutauit naturam, mox patefecit auctorem, et elementorum creator mutatione reuelatus est creaturae; 160. 6: Auctor est elementorum, qui elementa commutat; et naturam fecit ipse, qui contra naturam facere non laborat; Ps. Aug., Inter aestuosa et ripis tumentia flumina (HAULER, E.: Die dem hl. Augustin zugeschriebene Predigt über die Verwandlung von Wasser in Wein. WS 50 [1932] 136): Hoc fecit Christus in latice, quod certo tempore facit in uite. Quis enim alius radicem ex imbre maritat? Quis alius per occultas uenarum fibras stellatos palmites laqueat? Quis turgentes botros ac uelut in apices gemmatos impinguat, nisi is qui uniuersa prouocat et multiplicat?

${ }_{63}^{6}$ A severe judgement on Sedulius" "manieristische Vorstellung" in GLEI (n. 16) 146-148.

${ }^{64}$ The paternity of Hymn VII, explicitly attributed by Cassiodorus to the beatus Ambrosius (in psalm. 74. 8), is still discussed: one should refer to SimONETTI, M. (ed.): Ambrogio, Inni. Firenze 1988,90 (inauthenticity); BonAto, A. (ed.): Sant'Ambrogio, Inni. Milano 1992, 182-195 (authenticity); FonTAINE, J. (dir.): Ambroise de Milan, Hymnes. Texte établi, traduit et annoté, Paris 1992, 337-343 (probable inauthenticity); BANTERLE, G.: Introduzione. Le opere poetiche di sant'Ambrogio. In BANTERLE, G. BIfFI, G. - BIFFI, I. - MigliavacCA, L. (eds.): Sant'Ambrogio. Opere poetiche e frammenti. Inni - Iscrizioni-Frammenti [SAEMO 22]. Milano - Roma 1994, 11-22 (probable authenticity).

${ }^{65}$ SPRINGER (n. 7) 114: "Sedulius [...] feels it necessary to include such a colourful and descriptive passage in the episode and lingers lovingly over the sensual scene he has created."

${ }^{66}$ DeRmot SMALl (n. 46) 234-235.

${ }^{67}$ Dermot SMALL (n. 46) 230-231: "Christ [...] is the true vine who brings forth everything as His fruit (here we have again the recurring idea of Christ as creator) and who protects men in the same way as the vine leaves protect the grapes. This interpretation is of course inspired by Christ's words at John 15.1-5 [...], but it is Sedulius who makes the connection between Christ's metaphor and the miracle at Cana"; SPRINGER (n. 7) 115. 
allegorical tour de force: ${ }^{68}$ the poet explicitly recalls Ioh. 15:1-5 ( ${ }^{1}$ Ego sum uitis uera et Pater meus agricola est ${ }^{2}$ Omnem palmitem in me non ferentem fructum tollet eum et omnem qui fert fructum purgabit eum ut fructum plus adferat ${ }^{3}$ Iam uos mundi estis propter sermonem quem locutus sum uobis ${ }^{4}$ Manete in me et ego in uobis sicut palmes non potest ferre fructum a semet ipso nisi manserit in uite sic nec uos nisi in me manseritis ${ }^{5}$ Ego sum uitis uos palmites qui manet in me et ego in eo hic fert fructum multum quia sine me nihil potestis facere) but probably alludes also to other Scriptures, such as Is. 5:1-7 and Hier. 2:18.

For Sedulius, Christ is the fertile 'real vine' and, through the action of Virtus, gives birth to grapes which will not perish. We should appreciate the subtle efficacy of the adjective ferax, which underlines the fertility of Christ-vine but, almost homographic to uerax, also recalls the uera uitis of the Gospel, ${ }^{69}$ and the protective connotation of the substantive tegmen, which inevitably recalls the first line of Vergil's eclogues, already christianised by Damasus (3. 1: sub tegmine Christi), but, in this context, may also allude to the Origenian and Ambrosian theme of the umbra crucis. ${ }^{70}$ Not common is also the transitive use of the participle fructificans, which does not seem to have the meaning of fecundum, fructuosum reddere (ThLL VI 1. 1369. 6674), but rather that of generare, like in Tertullian ( $a d v$. Marc. II 4. 3): if we activate this resonance, Sedulius' image would reinforce the evocation of the creational power of the $\Lambda$ ó $\gamma$ os.

In this dense Christological context, the 'divine power' (uirtus) of 1.9 seems to deserve an attentive interpretation. At 1. 2, the same term indicated Christ's $\delta$ 'v $\alpha \mu 1 \zeta$, revealed by the miracle; in addition, in Sedulius Virtus regularly indicates the Son (pasch. carm. I 312-313: At Dominus, uerbum, uirtus, sapientia, Christus, / Et totum commune Patris), in any case indissolubly associated to the Father (I 293: Quae [scil.: ueteris miracula legis] genitor socia nati uirtute peregit). If I rightly understand the passage, with the expression uitis ... uirtute colona the poet means that Christ-uitis, incarnation of the Virtus (1.9) revealed by the wonder (1. 2: Virtutis documenta), also embodies the farmer (colonus $)^{71}$ who creates and fructifies (1. 10: fructi-

${ }^{68}$ For this aspect of Sedulius' poetry cf. GómEZ, R. M.: El Carmen Paschale de Sedulio como poema alegórico: el simbolismo de los números. Auster 13 (2008) 101-114.

${ }^{69}$ In this sense, it is not hard to understand the origin of the reading uerax, attested by the manuscripts T (Torino, Biblioteca Nazionale Universitaria, E. IV. 42, 7th century; $u$ - by a different hand; on this important Bobbian codex, the earliest and most complete Sedulian manuscript, to which Huemer referred as "E. IV. 44", cf. SPRINGER, C. P. E., The Manuscripts of Sedulius: A Provisional Handlist. Philadelphia 1995, 21-22, n. 50) and $\mathbf{O}$ (Città del Vaticano, Biblioteca Vaticana, Ottoboniano 35, 10th century).

${ }^{70}$ Cf. especially Ambr. spir. sanct. I 1 (MoRESCHINI, C. [ed.], Sant'Ambrogio, Opere dogmatiche II. Lo Spirito Santo [SAEMO 16]. Milano-Roma 1979, 51-53, n. 3) and, with regards to Christ as uitis and agricola (cf. infra), fid. IV 12. 168.

${ }^{71}$ This interpretation seems also to better correspond to the prose of the Opus Paschale (III 1: Vitis aderat uirtutis colonatu fructifera, sub aetheriae frondis umbraculo nutriens racemos spiritalis pampini semper amoenitate uicturos); GLEI (n. 16) 147, instead, believes that colona (reading of C [Chartres, Bibliothèque Municipale 100, 9th-10th centuries], also present in a correction of $\mathbf{G}$ [Paris, Bibliothèque Nationale, lat. 14143, 9th century], preferred by Huemer to colenda of the most part of the manuscript tradition) could hardly be interpreted as apposition of uirtute; he therefore proposes the conjecture coloni, and translates: "durch die (göttliche) Macht des Weinbauern". 
ficans) the vineyard of the Lord, whose grapes, differently from the uinea Domini of Is. 5:1-7, are destined to eternal life (inocciduas ... uuas). ${ }^{72}$

This interpretation would imply that for Sedulius the agricola of Ioh. 15:1-5 represents Christ, Dei uirtus et Dei sapientiam (I Cor. 1:24), who would be therefore at the same time uitis and agricola. ${ }^{73}$ The contrast to the Gospel is only apparent, as explained by Ambrose, who developed an exegetical intuition of Athanasius. ${ }^{74}$ By affirming that the Father and the Son, respectively indicated as agricola and uitis, pos-

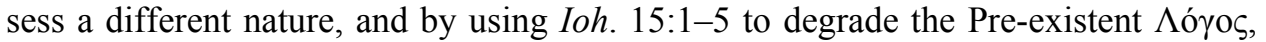
heretics insult both the Father and the Son (fid. IV 12. 157-162). Since He incarnated in a human body though conserving the same substance of the Father, for the Bishop of Milan Christ is at the same time vine and farmer, that is to say, fully human and fully God; ${ }^{75}$ Ambrose's argument is notably strengthened by the quotation of a prophecy directed by Jeremiah against Jerusalem, where the Son, and not the Father, spoke as husbandman (IV 12. 164-166):

Vitis enim (scil.: Christus) est, quia meas sustinet passiones, quandoquidem in illo nixa fragilis prius humana condicio faecundis rediuiuae fructibus pietatis adoleuit. [...] Si enim Filius incarnationis futurae loquitur sacramentum - quia impium est ut de Patre credas -, Filius est utique, qui supra dicit: Ego te plantaui uitem fructiferam; quomodo conuersa es in amaritudinem uitis alienae? (Hier. 2:21). Itaque et Filium uides esse agricolam, unius nominis cum Patre, unius operis, unius dignitatis atque substantiae. Ergo si et agricola et uitis est Filius, uitem utique secundum incarnationis accipimus sacramentum.

Also for Augustine, Jesus is at the same time uitis and agricola: this is a consequence of His identity in substance with the Father, and can be also demonstrated by Ioh. 15:3, where Jesus covers the function of the vinedresser, and not of the vine (in Ioh. tract. 80. 2):

Secundum hoc ergo uitis Christus, secundum quod ait: Pater maior me est (Ioh. 14:28): secundum autem id quod ait: Ego et Pater unum sumus (Ioh. 10:30), et ipse agricola est. [...] Denique cum de Patre tamquam de agricola dixisset quod infructuosos palmites tollat, fructuosos autem

\footnotetext{
${ }^{72}$ The Ecclesiological connotation of this image (denied by MAZZEGA [n. 50] 72) may be also responsible for the replacement of hydriae of the hypotext with lacus (8): if it is possible that the term just stressed the big dimensions of the vases (so MAZZEGA [n. 50] 70), it has to be remembered that, in connection with wine, it normally possesses the meaning of torcular (ThLL VII. 2. 864. 1-44), correspond-

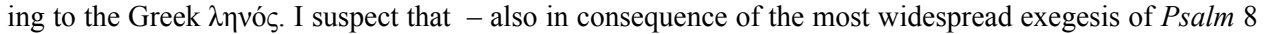
(cf. Aug. in psalm. 8. 1) - the poet wanted to allude to the Ecclesiological meaning of the wonder (cf. Ambr. spir. sanct. I 1: Ecclesia enim torcular est fontis aeterni, in qua caelestis uitis fructus exundat), foreshadowing the forthcoming exegesis of 11. 9-11.

${ }^{73}$ MAZZEGA (n. 50) 71: "Er hebt dadurch die göttliche Allmacht Christi, der Weinberg und Weinbauer zugleich ist, hervor." On the rhetorical aspect of the oxymoron uitis colona cf. SPRINGER (n. 7) 118. ${ }_{74}$ Athan. sent. Dion. 10 (PG 25, col. 493-495).

${ }^{75}$ On Sedulius' orthodox celebration of the coexistence in Christ of human and divine nature, $\mathrm{cf}$. DERMOT SMALL (n. 46) 229-230.
} 
purget ut plus afferant fructum; continuo etiam seipsum mundatorem palmitum ostendens: Iam uos, inquit, mundi estis propter sermonem quem locutus sum uobis (Ioh. 15:3). Ecce et ipse mundator est palmitum, quod est agricolae, non uitis officium.

Returning to Sedulius, we can appreciate the careful construction of the closing line, a precious uersus aureus: the poet makes use of a Vergilian tessera (georg. I 448: Heu male tum mitis defendet pampinus uuas) ${ }^{76}$ in a sort of (weak) 'Kontrastimitation' and spiritualisation of Vergil's diction: since the personified vine-leaf of the Georgics is unable to protect its grapes from the horrida grando (I 449), Christ's power is proclaimed superior to Nature. Finally, the rare adjective inocciduus, with its five syllables, powerfully emphasises an eschatological allusion to the caeleste mysterium of Resurrection and eternal life in Christ: ${ }^{77}$ this allegorical interpretation of the Cana account finds a good parallel in a sermon by Maximus of Turin (serm. 101.3):

Credendum est iam ex hoc mortalem hominem in inmortalitatem posse conuerti, quando uilis substantia in praetiosam est conuersa substantiam. [...] Facto enim hoc altius nescio quid demonstratur. Nam cum Dominus aquam uertit in uinum, non tam hoc operatur ne discumbentibus desit ebrietas, sed ut credentibus fiat aeternitas [...]. Ergo cum ex illa uili aqua uini optimi saporem uoluit gustare conuiuas, magis uoluit ex hac uili carne resurrectionis caelestis sapientiam gustare credentes. Nam hoc signo totum utique resurrectionis mysterium continetur. Aqua enim uilis pallida et frigida in uinum uersa, scilicet praetiosum rubeum uel ignitum, hoc significat hominis substantiam conditione uilem inbecillitate pallentem frigidam morte in resurrectionis gloriam conmutandam, quae est aeternitate praetiosa gratia colorata spiritu inmortalitatis ignita.

To sum up: in his rewriting of the miracle, Sedulius gives origin to a sort of Christological tableau (the Lord, together with natural elements, stands as the only protagonist) characterized by narrative essentiality and by a pronounced spiritual concern. His almost manieristic description of transformation as a process in fieri does not contradict the fact that many details reveal a potential theological (especially Christological) motivation, allowing the reader to interpret the rhetorical display of the Carmen Paschale as a means of emotional and meditative concentration.

${ }^{76}$ Cf. the important observations by MAZZEGA (n. 50) 73-74. On the influence of Vergil on Sedulius, see Grillo, A.: La presenza di Virgilio in Sedulio poeta parafrastico. In ChEVALlier, R. (ed.): Présence de Vergile. Actes du Colloques des 9, 10, 11 et 12 décembre 1976 (Paris E.N.S. Tours). Paris 1978, 185-194.

${ }^{77}$ Already in the Constitutiones Apostolorum, the miracle of Cana was interpreted as a sign of the Christological power, which can restitute aeternal life to deads (V 7. 28). Remigius of Auxerre, instead, interpreted the allegory of the inocciduas unas as referred to the secular enemies of the Church (HUEMER [n. 47] 338): Indeficientes fideles, nunquam perituros. Pampinus est folium uitis, quod a calore solis et iniuria imbrium protegit racemos. Ita diuina protectio fideles sanctae ecclesiae, ne deficiant, $\langle a b\rangle$ aduersantibus huius seculi protegit et munit. 
5. After this survey on the two most relevant Late Antique versifications of the Cana account, I would like to devote some attention to the literary (sub-)genre of the tituli historiarum, a very peculiar kind of biblical poetry placed at the crossroads between the genres of epigraphic (or supposedly epigraphic) poetry, abbreviated paraphrase, ${ }^{78}$ and descriptive 'Bildepigramm'; 79 the Marriage of Cana is treated in Prudentius’ Dittochaeon, Ps. Claudian's Miracula Christi, and Rusticus Helpidius' Tristicha historiarum testamenti ueteris et noui. The tituli present themselves as descriptions and explanations of pictured narratives from the Bible, and make use of specific stylemes for the 'presentification' of the biblical scenes, whose knowledge is a pre-requisite for readers. ${ }^{80}$ Even in the probable case that these tituli never worked as real captions for existing figurative cycles, we should recognise the peculiar 'inter-medial' nature of this literary form: the tituli involve their readers in a game of supplementation ('Ergänzungsspiel'), inducing them to activate that form of hermeneutical co-operation which leads to visualization. ${ }^{81}$ The following observations will regard both the formal features of the tituli and their ties with some of the most relevant theological aspects of the Cana account (the transformation of nature by the Lord; the role of the inaugural $\sigma \eta \mu \varepsilon i ̃ o v$ for the disciples' faith); in the conclusion I will also try to better determine how their peculiar interaction of verbal and visual semiosis has to be intended.

6. Prudentius' Dittochaeon, probably composed at the very beginning of the 5 th century, is constituted by forty-eight hexametrical tetrastichs dedicated to Old (I-XXIV) and New Testament events (XXV-XLVIII). The eighth epigram of this second half of the poem, which introduces a long section dedicated to Christ's miracles (XXXII-XXXVIII), is dedicated to Cana (125-128):

\section{Foedera coniugii celebrabant auspice coetu}

forte Galilaei; iam derant uina ministris.

${ }^{78}$ KARTSCHOKE (n. 1) 111-114 (the tituli are called 'Extremfälle kürzender Bibelparaphrase'); cf. also CHARLET, J.-L.: L'inspiration et la forme bibliques dans la poésie latine chrétienne du iii au vi ${ }^{\text {e }}$ siècle. In FontAine, J. - PiéTri, C. (eds.): Le monde latin antique et la Bible. Paris 1985, 613-643; KÄSSER, C.: Text, and Image in Prudentius' Tituli Historiarum. In ZimMERL-PANAGL, V. - WeBER, D. (eds.): Text und Bild. Tagungsbeiträge. Wien 2010, 151-165. LuBIAN, F.: I tituli historiarum tardoantichi come forma di „riscrittura biblica epigrammatica” - con un commento a Prud. ditt. XXXIV. Interférences 9 (2016).

${ }^{79}$ Cf. some pioneering observations by G. DOWNEY s.v. Ekphrasis. In RAC IV (1959) 929-930; Lausberg, M.: Das Einzeldistichon. Studien zum antiken Epigramm. München 1982, 557, n. 2; ARNULF, A.: Versus ad picturas. Studien zur Titulusdichtung als Quellengattung der Kunstgeschichte von der Antike bis zum Hochmittelalter. München 1997, 23-32. LUBIAN, F.: Il genere iconologico e i suoi rapporti con i Bildepigramme dell' Antichità. In GINESTE-GUIPPONI, M.-F. - URLACHER-BECHT, C. (eds.): La renaissance de l'épigramme dans la latinité tardive. Actes du colloque international de Mulhouse, 6-7 octobre 2011. Paris 2015, 211-227.

${ }^{80}$ SMOLAK, K.: Die Bibeldichtung als «Verfehlte Gattung». In STELLA, F. (ed.): La scrittura infinita. Bibbia e poesia in età medievale e umanistica. Firenze 2001, 27: "Der spätestens seit dem Dittochaeon des Prudentius literarisierten Gattung des Bildtitulus mangelte aber das narrative Element im höchstem Maß: Wer die jeweilige Perikope nicht kennt, kann sich aus den pointierten Epigramm den Inhalt in vielen Fällen nicht erschließen.”

${ }^{81}$ On the forms of hermeneutic integration implied by any reading process, see ISER, W.: The Reading Process: a Phenomenological Approach. In ISER, W.: The Implied Reader. Baltimore 1974, 274-294; COMETA, M.: La scrittura delle immagini. Letteratura e cultura visuale. Milano 2012, 116-142. 
Christus uasa iubet properanter aquaria lymfis

impleri, inde meri ueteris defunditur unda. ${ }^{82}$

Differently from what happens in Sedulius and in the tituli by Ps. Claudian and Rusticus Helpidius, Prudentius does not affirm that this was Christ's first sign: the primacy of the miracle can be only inferred from the position of the tetrastich, revealing the Dittochaeon's strongly integrated and narrativized structure. ${ }^{83}$

As in many other cases, the poet renounces to any explicit spatial and temporal contextualisation of the event: however, readers are invited to infer the episode's setting by the particular that the celebrants of the wedding were Galilaei. Poetic is the substitution of nuptiae of the hypotext with the periphrasis foedera (poetic plural, like uina) + coniugii (genetiuus pro adiectiuo, instead of the attested expression foedus coniugale), reinforced by an insisted alliteration (celebrabant auspice coetu). Prudentius does not mention the presence of Mary and the disciples; instead, he interestingly specifies that a crowd 'followed the wedding with participation' (auspice coetu) ${ }^{84}$ This detail, already object of attention in the glosses traditionally attributed to Iso of St. Gall $\left(\right.$ felici $\left.^{85}\right)$ and those perhaps by hand of Johannes Scotus Eriugena (augurante moltitudine ${ }^{86}$ ), is independent from John's account and has no precise parallels in other poetic rewritings. ${ }^{87}$ For this aspect, Prudentius is very distant from Juvencus, who highlighted the complete extraneousness of all participants from the ongoing events; the poet may have wanted to encourage the identification of his readers with the crowd of Cana, a town situated in the Galilaea gentium of Is. 9:1-2 which typologically embodied the ecclesia gentium. ${ }^{88}$ Concise and faithful to the Gospel is instead the transposition of the moment which precedes the miracle (iam derant uina ministris). In the first two lines, the adoption of the indicative imperfect is the main 396.

${ }^{82}$ Cunningham, M. P. (ed.): Aurelii Prudentii Clementis Carmina [CCSL 126]. Turnholti 1966,

${ }^{83}$ Even if a perfectly coherent, 1:1 correspondence between the Old and New Testament tituli of the Dittochaeon does not seem plausible, it is worth noting that the tetrastich VIII of the Old Testament section was dedicated to Moses' vocation at Horeb: in this case "beide Szenen leiten die öffentliche Karriere ihrer Helden ein" (DAVIS-WEYER, C.: Komposition und Szenenwahl im Dittochaeum des Prudentius. In DeichmanN, F. W. - FELD, O. - PESChlow, U. [Hrsg.]: Studien zur spätantiken und byzantinischen Kunst: F. W. Deichmann gewidmet. Bonn 1986, 25). The miracle of Cana was also recalled by Prudentius in the Cathemerinon IX (28-30: Cantharis infusa lymfa fit Falernum nobile, / Nuntiat uinum minister esse promptum ex hydria, / Ipse rex sapore tinctis obstupescit poculis), as the first one of gesta Christi insignia (IX 2). On the profound analogies between this hymn and the Dittochaeon, which allow to interpret the trochaic tercets of Cathemerinon as a sort of 'martialised' tituli, adapted to the form of the epinikion, fundamental is SMOLAK, K.: Der Hymnus für jede Gebetsstunde (Prudentius, Cathemerinon 9). WS 113 (2000) 229-230.

${ }^{84}$ Cf. Prud. c. Symm. 2. 708-709: Numquid et ille dies Ioue contulit auspice tantum / Virtutis pretium.

${ }^{85}$ Goldastus (Francofurti 1610), 12.

${ }^{86}$ Burnam, J. M.: Glossemata de Prudentio. Edited from the Paris and Vatican manuscripts. Cincinnati 1905, 95.

${ }^{87}$ The Galileans assisting to the celebration are positively connoted also in Nonnus' paraphrase (Ioh. evang. B, 1-6, 55-60); cf. SMOLAK, K.: Beiträge zur Erklärung der Metabole des Nonnos. JÖByz 28 (1984) 1-14; LIVREA (n. 15) 163.

${ }^{88}$ Cf. SMitMans (n. 21) 82-84. 
trace of a 'descriptivization' of the Gospel narrative: the original temporal succession is transposed in spatial-synchronic form, with a focus on the instant of the transformation ('photographed' at the present tense, with a typical effect of mise en relief), while the antecedents are recalled at the past tense.

In the second part of the tetrastich, dedicated to the narrative core of the episode (Ioh. 2:7), Prudentius more openly reveals his intention to elevate the Gospel's humble diction. He substitutes the Graecism hydrias, already attested since Cicero and very common in biblical Latin, with the hyperbatic periphrasis uasa ... aquaria, which includes a rare technical term (ThLL II 366. 29-33). Like in cath. IX 28 (and in Ps. Claud. carm. min. app. 21. 6, cf. infra), a typical poetic plural like lymphae ${ }^{89}$ replaces aqua of the Gospel. Finally, the conclusion shows a pronounced paronomastic effect, already experimented by Seneca (Phaedr. 512-513: Siue fons largus citas / Defundit undas). We should observe that Juvencus already used the term unda for Cana, but to denote the liquid before the transformation (II 147-148): in respect to his predecessor, Prudentius more directly emphasises the exceptional metamorphosis, since the wave is not made of water, but of exquisite wine.

Prudentius is certainly more interested in description than in any form of interpretation of the miracle $;^{90}$ nonetheless, two minor integrations to the Gospel are worthy of note. Firstly, by means of the very rare adverb properanter ${ }^{91}$ (cf. Nonn. Ioh.

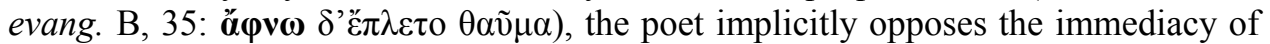
the miracle to the slowness of natural processes; this contrast is not unparalleled in the thought of the Fathers, e.g. in Augustine (cur. mort. 16. 19) ${ }^{92}$ and especially in the pseudo-Augustinian sermon Inter aestuosa et ripis tumentia flumina. ${ }^{93}$ Secondly, the definition of transformed wine as meri ueteris may also be a hint of the poet's interpretive approach. The adjective absorbs the connotation of bonum of Ioh. 2:10, ${ }^{94}$ while the substantive is a poetic ellipsis for merum uinum, like in Ps. Hil. hymn. Christ. 26, Sedul. pasch. carm. III 6, and Rust. Help. hist. testam. 56 (cf. infra). The term may

${ }^{89}$ MAAS, P.: Studien zum poetischen Plural bei den Römern. In MAAS, P.: Kleine Schriften. München 1973,528 .

${ }^{90}$ CALCAGNINI, D.: Tra letteratura e iconografia: l'epigramma Miracula Christi. VetChr 30 (1993) 29 rightly underlines that, at least in this case, Prudentius' tetrastich reveals "il prevalere dell'intento narrativo su quello esegetico".

${ }^{91}$ Before the two Prudentian attestations (perist. IV 14), the adverb - synonymic and co-radical of properatim - found only one poetic precedent (Lucr. V 300).

${ }^{92}$ Non enim quia in uinum aqua, cum uoluit dominus, repente conuersa est, ideo non debemus, quid aqua ualeat in elementorum ordine proprio, ab istius diuini operis raritate uel potius singularitate discernere.

${ }^{93}$ HAUleR (n. 62) 136: Hoc fecit tunc Christus cum latice, quod certo tempore facit in uite [...] Quae est tam repentina conuersio? In aqua uinum nascitur, in unda sapor latenter exoritur; greminat suauitas in uinis et non fructificat uitis; nulla exprimitur uua et feruescunt sine palmite uina.

${ }^{94}$ Similarly, in cath. IX 28 Prudentius used the metonymy Falernum nobile to celebrate the excellence of wine; cf. BIANCO (n. 5) 53: "Il Falerno era un vino pregiato di colore rosso rubino intenso. Il prudenziano Falernum viene dunque a essere la metonimia con cui il letterato esprime l'evangelico Io 2, 10 (quindi Falernum = una qualità buona del vino, e si tratta anche di un vino prevalentemente rosso), ma Prudenzio sembra limitarsi a indicare la qualità privilegiata del vino senza ulteriori sottolineature." 
not have the precise connotation of 'pure wine', being just a metonymy for the liquid $;$ " in any case, the purity of Cana's wine was in some cases explicitly recalled by exegetes (Aug. cons. evang. III 25. 72; Max. Taur. serm. 28. 1), so this detail may also contribute to stress the exceptionality of the miracle.

7. Probably composed around the middle of the 5th century and published for the first time by Camers in his edition of Claudian (Viennae 1510), the short poem entitled Miracula Christi (Ps. Claud. carm. min. app. $21=$ Anth. Lat. 879 R. ${ }^{2}$ ) is formed by nine elegiac couplets, each dedicated to an episode from Christ's life. The third distich, collocated after the Annunciation (I) and the Gifts of the Magi (II) and inaugurating the section with proper miraculous content (III-IX), is dedicated to Cana (5-6):

\section{Permutat lymphas in uina liquentia Christus \\ Quo primum facto se probat esse deum. ${ }^{96}$}

Distichs represent an extreme case of paraphrase 'by abbreviation and omission', 97 strongly conditioned by the nature of the chosen meter. Similarly to the tituli by Prudentius and Rusticus Helpidius, but also to the longer paraphrases of Juvencus and Sedulius, our epigram does not recall any of the spatiotemporal circumstances of the marriage feast. Like in Sedulius, Prudentius, and Rusticus Helpidius, the presence of Mary and the disciples is omitted; the anonymous author also suppresses the mention of servants and jars, both decisive for the transformation. ${ }^{98}$ The distich shows a rather schematic organization: the transformation is synthetically recorded in the hexameter (Ioh. 2:7), while the pentameter offers a simple amplification of Ioh. 2:11, highlighting the wonder's theophanic nature. In the first line, the author does not renounce to the ennoblement of the Gospel diction: as in Prudentius, aqua is substituted by the canonical poetism lymphae, while the exornative epithet liquentia derives from Vergil (Aen. V 238: proiciam in fluctus et uina liquentia fundam; V 776: Proicit in fluctus ac uina liquentia fundit); the 'formales Schmuckmittel' constituted by the alliteration lymphas ... liquentia also stresses the excellence of wine, ${ }^{99}$ while the rhythmic acceleration impressed by the fourth and fifth dactylic feet after the three spondees gives the impression of a sudden, impetuous pouring of the liquid. As for what pertains literary models, the distich reveals a probable influence by Paulinus of Nole's Carmen XXVII. ${ }^{100}$ In Paulinus, the wonder of Cana represents a sign of Christ's di-

${ }^{95}$ So PILlinger, R.: Die tituli historiarum oder das sogenannte Dittochaeon des Prudentius. Versuch ein philologisch-archäologischen Kommentars. Wien 1980, 85.

${ }_{96}$ Hall, J. B. (ed.): Claudii Claudiani Carmina. Leipzig 1985, 287; cf. now LubIAN, F.: Un caso di riscrittura metrica ultrabreve dei Vangeli: i distici Miracula Christi (Ps. Claud. carm. min. app. $21=$ Anth. Lat. 879 R. ${ }^{2}$ ). Graecolatina Pragensia 26 (2016) 87-109.

${ }^{97}$ I am referring to the categories introduced by ROBERTS (n. 1) 108-127, whose study, in any case, does not take into account the tituli historiarum.

${ }_{98}^{98}$ LAUSBERG (n. 79) 220.

${ }^{99}$ LAUSBERG (n. 79) 220.

${ }^{100}$ The author of the Miracula Christi seems to have known Paulinus' poetry: cf. also Ps. Claud. carm. min. app. 21. 2: concipiat salua uirginitate deum $\sim$ Paul. Nol. carm. 25. 154: Quae genuit salua uirginitate deum; Ps. Claud. carm. min. app. 21. 9-10: Editus ex utero caecus noua lumina sentit / Et stupet ignotum se meruisse diem $\sim$ Paul. Nol. carm. 23. 293: Ex utero et caecum noua lumina fecit habere. 
vine nature, and is defined His 'first deed'. The most striking verbal parallel between the ninth Natalicium and our distich consists in the common and exclusive use of the verb permutare; note that the present tense is functional to the tituli's canonical pursuit of 'presentification' (50-52):

Siue dies eadem magis illo sit sacra signo,

Quo primum deus egit opus, cum flumine uerso

Permutauit aquas praedulcis nectare uini. ${ }^{101}$

As already anticipated, the pentameter is dedicated to the interpretation of the $\sigma \eta \mu \varepsilon i ̃ o v$ as a demonstration of Christ's divine nature, formally emphasised by means of the alliteration primum ... probat $^{102}$ Like in the two first distichs (2: concipiat ... deum; 4: suscipe tura deus), the word deum receives a strong emphasis by its position; more precisely, as underlined by M. Lausberg, the words Christus and deum in clausula reinforce the concept of Christ's divine nature. ${ }^{103}$ After having been preannounced (1: praescia; 3 : praenuntia munera), Christ's divinity is finally demonstrated: ${ }^{104}$ our distich represents therefore a good hinge-point between the two introductory distichs and the compact section dedicated to the wonders. In contrast to Juvencus' paraphrase (II 151-152), here we do not find any explicit mention of the miracle's effects on the disciples; ${ }^{105}$ it is in any case probable that the focus on the theophany aimed not only to celebrate the Lord's exceptional power, but also to implicitly introduce the theme of faith, central in many of the following distichs (VII, VIII, IX). This simple devotional aim seems more coherent with the purpose of the entire Miracula Christi to "celebrate and glorify the figure of Christ" 106 than the evocation of Cana's baptismal 'Figuraldeutung' as supposed by other scholars, who believed that our poem was composed to accompany, as a real metrical caption, a mosaic or fresco cycle in a baptistery. $^{107}$

${ }^{101}$ It is also interesting that Paulinus, like the already mentioned (n. 64) hymn Inluminans altissimus of Ambrosian attribution, shares with the Miracula Christi the mention of the Gifts of the Magi and Cana as revelations of the Lord's divinity. Together with the Baptism, these two episodes were also asso-

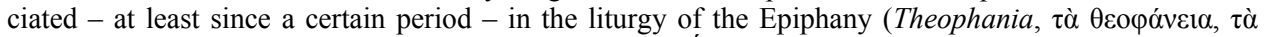

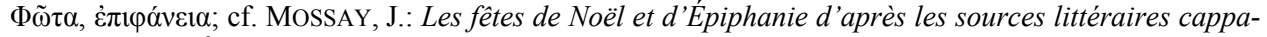
dociennes $d u I V^{e}$ siècle. Louvain 1965, 21-30), as attested among others, in the second quarter of the 5th century, by Peter Chrysologus (serm. 160. 7: Tribus autem modis hodie Christi deitas est probata: magorum munere, Patris testimonio, aquae mutatione in uinum). It is therefore possible that the association of the Epiphany and the miracle of Cana with the purpose of demonstrating Christ's divinity has been conceived under the influence of the liturgy in use around the middle of the 5th century (or of its iconographic repercussions).

${ }^{102}$ Cf. Prud. ham. 658-659: Multa ut taceam, uel sola benignum / Res probat esse deum.

${ }^{103}$ LAUSBERG (n. 79) 220; differently CALCAGNINI (n. 90) 29: "A nostro avviso quello che preme all'autore è sottolineare la duplice natura umana e divina in Cristo"; but Christ's orthodox dyphysism is rather the central theme in the antecedent distich (4: Myrrham homo, rex aurum, suscipe tura deus).

${ }^{104}$ Cupaiuolo, G.: Note ai Miracula Christi (A. L. 879 R.). In Polyanthema. Studi di letteratura cristiana antica offerti a Salvatore Costanza. Messina 1989, II 193.

${ }^{105}$ LO CiCERO, C.: I carmi cristiani di Claudiano. AAPal 36 (1976-1977) 36-37.

${ }^{106}$ Cupaiulolo (n. 104) 180.

107 TuRCIO, G.: Sull'epigramma "Miracula Christi" attribuito a Claudio Claudiano. RAC 5 (1928) 341; CALCAGNiNi (n. 90) 31-32. 
8. Our last example is taken from the Tristicha historiarum Testamenti ueteris et noui, a collection of twenty-four tristichs with biblical theme composed by Rusticus Helpidius at the end of the 5th or perhaps at the beginning of the 6th century. The first part of the work shows a typological architecture, since the first sixteen tristichs are constituted by couples of Old and the New Testament episodes; the last eight tituli, instead, all regard Christ's life. The nineteenth tristich is dedicated to Cana (55-57):

Insipidi quondam latices: elementa saporem

Fragrantis sumpsere meri, nam prouidus Auctor

Munera laetitiae, uirtutum exordia, fecit. ${ }^{108}$

Helpidius' rewriting has an almost abstract character: nothing is told about context, human actors, and concrete moments of the transformation, its absolute protagonists being just natural elements. The term elementa (cf. the hymn Inluminans altissimus, 19-20: Elementa mutata stupet / Transire in usus alteros), with its recognisable Lucretian patina, stresses the cosmic power of Christ over nature: as Prudentius wrote - in Lucretian terms - in the Apotheosis, it is not surprising that the architect of the universe, who gave origin to natural elements (rerum species and elementa mundi), could also operate their sudden transformation. ${ }^{109}$ In this context, the attributes applied to water and wine may not be merely exornative, ${ }^{110}$ but rather show an interpretive (perhaps already exegetical) approach to the wonder. Before the transformation, water (latices $^{111}$ is a typical poetic synonym for aquae, already used for Cana by Sedulius, who could have represented a model for Helpidius in this and other cases ${ }^{12}$ ) is defined 'flavourless', with an adjective attested for the first time by Paulinus of Nole (epist. 39. 4) and very rare in poetry. ${ }^{113}$ The contrast with the good taste of wine is explicit, and emphasised by a framing figura etymologica (Insipidi ... saporem; notable is also the alliteration between saporem and sumpsere). This integration to the Gospel was with few doubts influenced by contemporary exegesis: the opposition between the dullness of water and the good flavour of wine was in fact a recurrent theme in the Fathers, for whom the transformation of insipid water into wine allegorically represented the flavoursome intervention of Grace on the Mosaic Law. If some interpreta-

${ }^{108}$ Di Stefano, A. (ed.): Elpidio Rustico, Tristicha - De Christi Iesu beneficiis. Introduzione, testo, traduzione e commento. Napoli 2013, 96.

109 The poet alluded here to the multiplication of loaves and fishes (apoth. 731-735).

${ }^{110}$ Di STEFANO (n. 108) 117 speaks of "un erudito e per certi versi macchinoso giro di parole per indicare i due elementi chiave dell'episodio".

${ }^{111}$ With Di Stefano, I adopt the reading latices of the editio princeps, by all subsequent editors corrected in the genitive latičs (referred to elementa); the ellipsis of the copula is not rare in Helpidius, and this conservative reading consents to avoid the lengthening in arsis of the genitive desinence.

${ }^{112}$ The parallels are in this case both exegetical (Christ's first sign) and lexical (latices; saporem; merum); cf. MAZZEGA (n. 50) 63-69. For significant verbal affinities, see esp. Sedul. pasch. carm. III 123-125: Posteriusque latens subitam furata salutem / Extrema de ueste rapit siccisque fluentis / Damnauit patulas audax fiducia uenas $\sim$ Rust. Help. hist. testam. 61-63: Haec mulier tactu uestis furata salutem est, / Siccauitque fides uenas, fluuiumque pudendum: / Pulchra fides, cui uis cogendi magna Tonantem.

${ }^{113}$ The only other attestation appears in Avit. carm. II 397, where the 'insipid sin' (insipido ... reatu) of Lot's wife is based on Aug. civ. XVI 30. 
tions are mainly centred on a baptismal typology (Gaud. tract. 9. 44; Max. Taur. serm. 65. 2), the typological structure of the Tristicha seems to reveal a better affinity to allegorical interpretations focused on the fulfillment of the Old Alliance in the New Testament. In this sense, the taste of wine was connected by Augustine - who uses the same rare adjective insipidus to allude to the flavourlessness of the prophetic books, when they are read without seeing in them the vivifying presence of Christ to the New Testament revelation; without Christ's intervention, in fact, the Scripture remains inert and dull (in Ioh. tract. 9. 5-6):

Mutauit ergo aquam in uinum Dominus noster Iesus Christus, et sapit
quod non sapiebat, inebriat quod non inebriabat. [...] Cum autem ipsam
aquam conuertit in uinum, ostendit nobis quod et Scriptura uetus ab ipso
est: nam iussu ipsius impletae sunt hydriae. A Domino quidem et illa
Scriptura; sed nihil sapit, si non ibi Christus intellegatur. ${ }^{114}$

As for what pertains the attribute of wine (like in Prudentius, meri is a typical poetic substitute for meri uini), I accept the correction fragrantis for the attested flagrantis recently proposed by A. Di Stefano. The oscillation between $-l-$ and $-r$-, in fact, is frequent in all Latinity (ThLL, VI 1. 1237. $68-1238.8$ ), and it seems more probable that Helpidius wanted to allude not the sparklingness of Cana's wine, but rather to its good fragrance; this attribute would be both more characteristic for the liquid ${ }^{115}$ and more appropriate to constitute a polar opposition to the insipidity of water. Furthermore, a fragrant perfume is always sign of the presence of the Lord, since from Cant. 1:2 and II Cor. 2:14-16. On these biblical passages was based Gregory of Elvira's interpretation of the wine's fragrance: for him, the 'new wine' of Marc. 2:22, as opposed to the old one (the Mosaic law), represented the Gospel, sweet beverage which pours from the water of baptism and can transform the insipid soul of Christians through the infusion of taste and smell (in Cant. 1. 12: Quid est enim de aqua uinum, nisi quod anima, quae retro fuerat terrena, insipida et aquata, in merum Spiritus conuersa praestantior sapore facta est et odore). Also Maximus of Turin, who defined the liquid substantia boni odoris (serm. 101. 3), reconnected the good smell of the wine of Cana to the fragrance of Christ (serm. 65. 2: Vt uini uice sapiamus quod bonum est redoleamus quod suaue est et possimus dicere illud apostoli: "Quoniam Christi bonus odor sumus deo”); finally, in Caesarius of Arles Cana's wine testimonies the bonus odor of the Divine grace (serm. 168.4). ${ }^{116}$ Helpidius' adjectival ampli-

\footnotetext{
${ }^{114}$ Cf. also Caes. Arel. serm. 168. 4: Bonum quidem est Vetus Testamentum, sed sine spiritali intellectu uanescit in littera; nouum uero odorem uitae reddit in gratia.

${ }^{115}$ Ps. Cypr. sing. cler. 7: uini odoriferi sola fragrantia; Arn. Iun. in Psalm. prol., CCSL 25, 3. 9: uina fragrantia; lib. ad Greg. 20, CCSL 25A, 234. 32: fragrantia uina; Isid. orig. XVI 4. 7, 11. 8: uinum fragrat.

${ }^{116}$ At least in Nonnus of Panopolis, the wine's perfume plays a structural role in the paraphrase: in fact, even if it is true that the poet described the transformation of water 'into a stream of scintillating

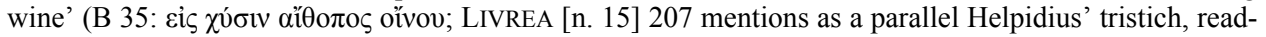
ing flagrans with all editors before A. Di Stefano), he also defines 'fragrant' (with hypallage) the water
} 
ficatio, far from being merely exornative, reveals therefore to be the textual hint of an allegorical approach to the Gospel: the 'implied exegesis' revealed by these attributes finds precise parallels in the thought of the Fathers and is coherent with the typological structure of the whole work.

In the second half of the tristich, like Sedulius and the author of the Miracula Christi, Helpidius affirms that at Cana found place Christ's first miracle (uirtutum exordia). The iunctura munera laetitiae, of clear Propertian origin (I 10. 12: Accipe commissae munera laetitiae), has been already used in relation to wine - and in the same line position - by Dracontius (laud. Dei I 174-175: munera laetitiae spondens pendentibus uuis), where the expression was equivalent to munera laeta. ${ }^{117}$ Like Juvencus before him, Helpidius - who called 'joyful' the wine of Cana in the Carmen de Christi Iesus beneficiis (87: Laetaque uina toris et fercula reddita mensis) alludes therefore to the theme (derived from the Psalter) of the spiritual joy brought by wine.

In the last line, Christ is called prouidus Auctor, perhaps showing the influence of an auditive memory from Stat. Theb. X 329 (Iamque ipsum defecit opus, cum prouidus Actor). ${ }^{118}$ The epithet, derived from the Stoic tradition, was common to designate the creational role of the Christian God, ${ }^{119}$ often in association with synonyms like conditor or factor; ${ }^{120}$ its connection with the attribute prouidus ${ }^{121}$ is instead a significant Helpidian innovation (cf. also benef. 34: uitae prouidus Auctor), which well demonstrates the poet's ability in the re-elaboration of pre-existing pagan and Christian poetic material. ${ }^{122}$

Even from this brief case study, we can observe that Helpidius' Tristicha represent a significant innovation in respect to the antecedent tituli historiarum. Less interested in the transformation itself and more oriented to its spiritual interpretation, Helpidius shows in fact the influence of Sedulius in his attempt to transpose the Gospel episode in a sort of condensed 'meditative panel'; his dense and sometimes sententious diction and his didactic intonation have therefore to be judged functional to such project.

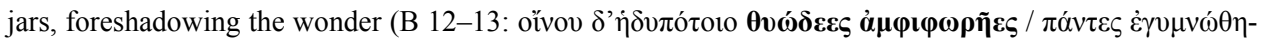

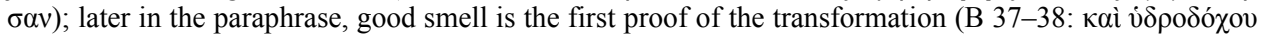

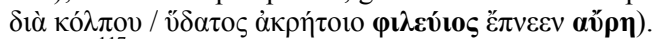
1985,273

${ }^{117}$ Moussy, C. - CAmus, C.: Dracontius, Euvres. Tome I: Louanges de Dieu, Livres I et II. Paris

${ }^{118}$ Di STEFANO (n. 108) 117.

${ }^{119}$ BRAUN, R.: Deus Christianorum. Recherches sur le vocabulaire doctrinal de Tertullien. Paris 1977², 344-346; cf. already Act. 3:15, 24:5; Hebr. 2:10, 12:2.

${ }^{120}$ Carm. adv. Marc. I 40, IV 24; Iuvenc. III 503; Prud. cath. X 135; apoth. 74; ham. 299; psych. 623; c. Symm. II 213; perist. V 37, X 318; Paul. Nol. carm. 6. 55; Ps. Prosp. prov. 106, 118, 149, 219 , 405, 616; Sedul. carm. pasch. III 113, V 16, 151, 249; hymn. 2. 5; cf. also Rust. Help. benef. 34, 72; hist. testam. 56.

${ }^{121}$ The term prouidentia also derives from the philosophic tradition, being the translation of $\pi \rho$ ó$^{-}$ $\gamma v \omega \sigma ı \zeta$ and $\pi \rho o ́ v o t \alpha ;$ prouidus, already sporadically attested in pagan poetry (Ilias Latina 920: Prouida Iuno; Claud. Hon. VI cos. 352: prouidus Aether), was therefore a fitting epithet for the Christian God (cfr. e.g. Prud. psych. 614; Drac. laud. Dei I 511; Avit. carm. IV 344).

${ }^{122}$ Di Stefano (n. 108) 117-118.
} 
9. As we have seen, with the exception of Rusticus Helpidius the metamorphosis of water was described in our poetic rewritings as a process in fieri, sometimes with the use of a 'commentative' present tense (Dittochaeon; Miracula Christi). A similar focus on the decisive instant of transformation was also typical for the Late Antique representations of this episode.

Already since its first attestations (the scene appears in funerary contexts since the beginning of the 3rd century, the oldest extant representation being that of the vault of an arcosolium from the Catacombs of Marcellinus and Peter), ${ }^{123}$ the miracle of Cana finds a stable iconographic scheme in the image of a young, beardless Christ standing with tunic and pallium and extending His rod towards one of the jars surrounding Him; if at the beginning Christ was always represented alone, in later formulations He might be accompanied by attendants (usually two) pouring water into the jars, by some disciples, or also the Virgin. In the first half of the 4th century, this scene was represented in many sarcophagi from Italian and Gallic ateliers, ${ }^{124}$ where this iconographic scheme was repeated with few variations (frequent is the representation of Christ with a disciple, as he touches with a rod one of the jars). ${ }^{125}$ Even after the intense renewal of the Western iconographic tradition at the end of the 4 th century, the episode of Cana continued to be part of the Palaeo-Christian repertoire, with slight variations: worthy of mention are in particular a mosaic from the Baptistery of S. Giovanni in Fonte (Neaples), ${ }^{126}$ one wooden panel from the door of Santa Sabina on the Aventine, ${ }^{127}$ a mosaic from the 'Christological register' of Sant'Apollinare Nuovo in Ravenna, made unrecognizable by heavy restorations (the original aspect is conveyed by a 17 th-century drawing), ${ }^{128}$ and an ivory panel from the back seat of the throne of the Ravennate Archbishop Maximianus. ${ }^{129}$ Together with other miracles, our episode was also represented in costly objects like a Roman ivory diptych whose two wings are now conserved in Berlin (SMB - Preußischer Kulturbesitz, Museum für Spätantike und Byzantinische Kunst, Ident. Nr. 2719) and Paris (Musée du Louvre,

${ }^{123}$ Wilpert, J.: Die Malereien der Katakomben Roms, mit 267 Tafeln und 54 Abbildungen im Text. Freiburg im Breisgau 1903, 301-304. 309-310.

${ }^{124}$ WILPERT, G.: I sarcofagi cristiani antichi. Volume secondo, Testo. Città del Vaticano 1932,

${ }^{125}$ ReCiO Veganzones, A.: Recensione a: C. Moreira Azevedo, O milagre de Caña na iconografía paleocristã, I. Porto 1986. RAC 63 (1987) 452-456; M. P. DEL Moro, s. v. Nozze di Cana. TIP 2000, 232-234; DulAEY, M.: Symboles des Evangiles (I ${ }^{e r}$-VI $I^{e}$ siècles). Paris 2007, 271-277.

${ }^{126}$ MAIER, J.-L.: Le Baptistère de Naples et ses mosaïques: étude historique et iconographique. Fribourg 1964, 33-34, 88-92; tab. IV.

127 Jeremias, G.: Die Holztür der Basilika S. Sabina in Rom. Tübingen 1980, 53-54.

${ }^{128}$ DeichmanN, F. W.: Ravenna. Hauptstadt des spätantiken Abendlandes. Wiesbaden 19691976, II.1, 162.

${ }^{129}$ CECCHELLI, C.: La cattedra di Massimiano e altri lavori romano-orientali. Roma 1936, II, tab. II-IV; VolBACH, W. F.: Elfenbeinarbeiten der Spätantike und des frühen Mittelalters. Mainz am Rhein 19763 , 93-94, tab. 72-74; BoviNI, G.: La Cattedra eburnea del Vescovo Massimiano di Ravenna. Ravenna 1990, 29-30. 
Département des objets d'art, Inv.-Nr. OA 7876-7877-7878), ${ }^{130}$ or the Ravennate ivory diptych of the Milan cathedral Treasury. ${ }^{131}$

If I correctly understand the mechanism underlying their literary experiment, the tituli historiarum find in such simple images their most probable iconographic 'models': ${ }^{132}$ by saying this, I do not mean that the tituli necessarily had to be poetic transpositions of singular, pre-existing representations, but simply that this epigrammatic (sub-)genre, as an autonomous literary product, flourished in a 'scopic regime' characterized by stable and repeated iconographic schemes, familiar to poets and audience: it is in the fold of such widespread visual habits that the tituli developed their peculiar form of abbreviated 'inter-medial re-writing' of the Bible.

Institut für klassische Philologie, Mittel- und Neulatein

Universität Wien

francesco.lubian@univie.ac.at

${ }^{130}$ VoLBACH (n. 129) 80-81, tab. 60; KÖTZSCHE, L.: 406., 407. Plaques with scenes of the infancy and miracles of Christ. In WeItzMAnN, K. (ed.): Age of Spirituality. Late Antique and Early Christian Art, Third to Seventh Century: Catalogue of the Exhibition at the Metropolitan Museum of Art, November 19, 1977 through February 12, 1978. New York 1979, 446-448.

${ }^{131}$ DELBRÜCK, R.: Das fünfteilige Diptychon in Mailand (Domschatz). Bonner Jahrbücher 151 (1951) 96-107; VolBACH (n. 129) 84-85, tab. 63.

${ }^{132}$ The term is used in the sense discussed by YACOBI, T.: The Ekphrastic Model: Forms and Functions. In Robillard, V. - JongeneEl, E. (eds.): Pictures into Words. Theoretical and Descriptive Approaches to Ekphrasis. Amsterdam 1998, 21-34, and therefore referred to cases in which "the discourse re-presents in language some visual common denominator" (in our perspective, an iconographic scheme) rather than a single, identifiable figurative work. 